Carmichael, Sarah K., Ferry, John M., and McDonough, William F., 2008, Formation of replacement dolomite in the Latemar carbonate buildup, Dolomites, northern Italy: Part 1. Field relations, mineralogy, and geochemistry. American Journal of Science, v. 308, no. 7, p. 851-884. Archived in NC DOCKS with permission of the editor. (ISSN: 0002-9599)

[American Journal of Science, Vol. 308, September, 2008, P. 851-884, DOI 10.2475/07.2008.03]

\title{
FORMATION OF REPLACEMENT DOLOMITE IN THE LATEMAR CARBONATE BUILDUP, DOLOMITES, NORTHERN ITALY: PART 1. FIELD RELATIONS, MINERALOGY, AND GEOCHEMISTRY
}

\author{
SARAH K. CARMICHAEL*, JOHN M. FERRY**†, and \\ WILLIAM F. MCDONOUGH***
}

\begin{abstract}
Replacement dolomite in the Latemar carbonate buildup, northern Italy, formed when limestone was infiltrated by and reacted with $\mathrm{Mg}$-rich fluid. It occurs in discrete bodies in sharp contact with unreacted limestone. The dolomite developed in a nearly orthogonal lattice of vertical columns (replacement of limestone breccia pipes) and sheets (replacement along fractures and limestone-dike contacts) and of nearly horizontal bedding-parallel sheets and tubes. Mapped patterns of replacement dolomite directly image that part of the plumbing system in which the amount of fluid flow was sufficient to form dolomite. Decreases in the proportion of dolomite relative to limestone and in the proportion of vertical relative to horizontal dolomite-limestone contacts with increasing elevation indicate that the overall direction of fluid flow was upward and then outward along more permeable bedding horizons. Dolomite is significantly enriched in $\mathrm{Fe}, \mathrm{Mn}$, and $\mathrm{Zn}$, as well as in $\mathrm{Mg}$, relative to calcite in precursor limestone but not in $\mathrm{Cu}, \mathrm{Ni}, \mathrm{Co}, \mathrm{Cr}, \mathrm{Ba}$, or $\mathrm{Pb}$. The $\mathrm{Fe}, \mathrm{Mn}$, and $\mathrm{Zn}$ content of dolomite varies spatially within outcrops from the scale of meters down to the micron scale of oscillatory growth zoning in individual dolomite crystals. The variation is interpreted in terms of a dolomitizing fluid that, unlike unmodified seawater, contained significant amounts of $\mathrm{Fe}, \mathrm{Mn}$, and $\mathrm{Zn}$, as well as of $\mathrm{Mg}$, and whose composition varied in space at a range of scales and in time at the site of growth of individual dolomite crystals. A nearly complete overlap in the $\delta^{13} \mathrm{C}$ of dolomite $\left(2.0-4.6 \%\right.$, VPDB) and calcite $(1.1-4.0 \%)$ is evidence that the $\delta^{13} \mathrm{C}$ of most dolomite was inherited directly from the calcite precursor. Measured $\delta^{18} \mathrm{O}$ of dolomite has a wide range $(21.8-27.7 \%$, VSMOW) overlapping with that of calcite $\left(23.4-28.5 \%\right.$ ) but shifted to lower values. Dolomite with $\delta^{18} \mathrm{O}<23.4$ permil could not have been equilibrium with any analyzed calcite at any temperature. The ranges in $\delta^{18} \mathrm{O}_{\text {Dol }}$ and $\delta^{18} \mathrm{O}_{\mathrm{Cal}}$ and values of $\delta^{18} \mathrm{O}_{\text {Dol }}<23.4$ permil both indicate that $\delta^{18} \mathrm{O}$ of calcite and dolomite were set by oxygen isotope exchange with the same fluid over a range of temperatures, with isotopically different fluids, or both.
\end{abstract}

\section{INTRODUCTION}

The formation of dolomite is a longstanding problem for which many explanations have been proposed (reviewed, for example, by Land, 1985; Machel and Mountjoy, 1986; Hardie, 1987; Budd, 1997; Warren, 2000). The consensus is that most dolomite in the geologic record formed by replacement of calcite (Land, 1985; Hardie, 1987; Budd, 1997). Using ideal mineral compositions and molar volumes of minerals from Holland and Powell (1998), the reaction is:

$$
(2.0-0.26 \mathrm{x}) \mathrm{CaCO}_{3}+\mathrm{Mg}^{2+}+0.26 \mathrm{xCO}_{3}^{-2}=\mathrm{CaMg}\left(\mathrm{CO}_{3}\right)_{2}+(1-0.26 \mathrm{x}) \mathrm{Ca}^{2+},
$$

where $\mathrm{x}=0$ corresponds to the end-member case of replacement at constant oxygen and carbon, and $\mathrm{x}=1$ corresponds to the end-member case of constant-volume replacement. The essential problem of the formation of replacement dolomite then reduces to identifying a fluid source for $\mathrm{Mg}$ (as well as $\mathrm{CO}_{3}^{-2}$ if $\mathrm{x}>0$ ) and a mechanism

\footnotetext{
*Department of Geology, Appalachian State University, Boone, North Carolina 28608, USA USA

**Department of Earth and Planetary Sciences, Johns Hopkins University, Baltimore, Maryland 21218,

***Department of Geology, University of Maryland, College Park, Maryland 20742, USA

${ }^{\dagger}$ Corresponding author: jferry@jhu.edu
} 
for pumping fluid that is capable of delivering sufficient quantities of $\mathrm{Mg}$ (and, $\mathrm{CO}_{3}^{-2}$ if $x>0$ ) to the site of reaction (1) and removing Ca from it. The likely fluid that formed much of the dolomite in the rock record is either seawater or a seawaterderived fluid (Land, 1985; Hardie, 1987; Budd, 1997).

Because it is implausible that a single dolomitizing fluid or a single pumping mechanism explains all replacement dolomite in the geologic record, detailed studies of individual occurrences make significant contributions to a general resolution of the "dolomite problem." These efforts are most successful if a broad range of field, mineralogical, chemical, and isotopic data are considered together (Budd, 1997). As a landmark example, Wilson and others (1990) concluded from a variety of data that replacement dolomite in the Latemar carbonate buildup, Dolomites, northern Italy, developed from hydrothermal convection of seawater through Triassic limestone driven by heat from the nearby Predazzo igneous complex. Our investigation revisits the formation of replacement dolomite in the Latemar buildup for three reasons. First, the area remains an outstanding field laboratory. Partially dolomitized limestone is superbly exposed by glaciation over horizontal dimensions of $\sim 10 \mathrm{~km}^{2}$ and a vertical dimension of $\sim 800 \mathrm{~m}$. Because of differences in color and texture, dolomite can be easily distinguished from limestone and mapped in the field. The stratigraphy of the limestone is simple and rocks are only slightly deformed. Second, technical advances in stable isotope and trace element microanalysis since 1990 allow for both new and more abundant geochemical data to be collected for dolomite and unaltered limestone. Third, developments in the application of transport theory to problems of chemically reactive fluid flow during metamorphism (for example, Ferry and Gerdes, 1998; Baumgartner and Valley, 2001; Ferry and others, 2002; Ague, 2003) provide a new theoretical framework to quantitatively interpret field and geochemical data for the Latemar buildup in terms of fundamental properties of the flow system that produced replacement dolomite. The first paper in the pair (Part 1) reports the field relations between dolomite and unaltered limestone and major-element, minor-element, traceelement, and stable isotope analyses of calcite and dolomite. The field and laboratory data are analyzed with simple considerations of transport theory in the companion paper (Part 2) to identify a previously unrecognized kind of dolomitizing fluid, to determine the amount of fluid flow, and to place quantitative constraints on the duration of flow.

\section{GEOLOGIC SETTING}

The Latemar carbonate buildup is located $\sim 5 \mathrm{~km}$ north of the town of Predazzo in the Dolomites of the Southern Alps, northern Italy (fig. 1). Limestones of the Latemar and adjacent Monte Agnello buildups represent Middle Triassic (Anisian and Ladinian Ages) atolls. Time-equivalent surrounding basinal shales and turbidites constitute the Livinallongo Formation. Underlying stratigraphic units include the Triassic Contrin and Werfen Formations (shallow-water platform carbonates and marl, respectively), the Permian Bellerophon Formation (siliceous dolomitic limestone, limestone, and minor evaporites), and Permian volcanic rocks.

The Latemar is one of numerous Triassic carbonate buildups in the Dolomites that developed in multiple marine basins formed by regional extension and strike-slip faulting (Blendinger, 1985; Doglioni, 1987). The Latemar buildup specifically has been subject of many stratigraphic and sedimentological studies (Rossi, 1967; Cros, 1977; Goldhammer, ms, 1987; Harris, ms, 1988; Dunn, ms, 1991; Yose, ms, 1993; Brack and others, 1996; Egenhoff and others, 1999; Preto and others, 2001). The Triassic carbonate rocks are divided into three stratigraphic units and three sedimentary facies. A central lagoonal facies (fig. 2) is composed of two stratigraphic units: the Anisian Lower Edifice (300-350 m of nearly flat-lying, thickly-bedded to massive grainstones of dasyclydacean algae that represent shallow subtidal deposition and cementation) and 


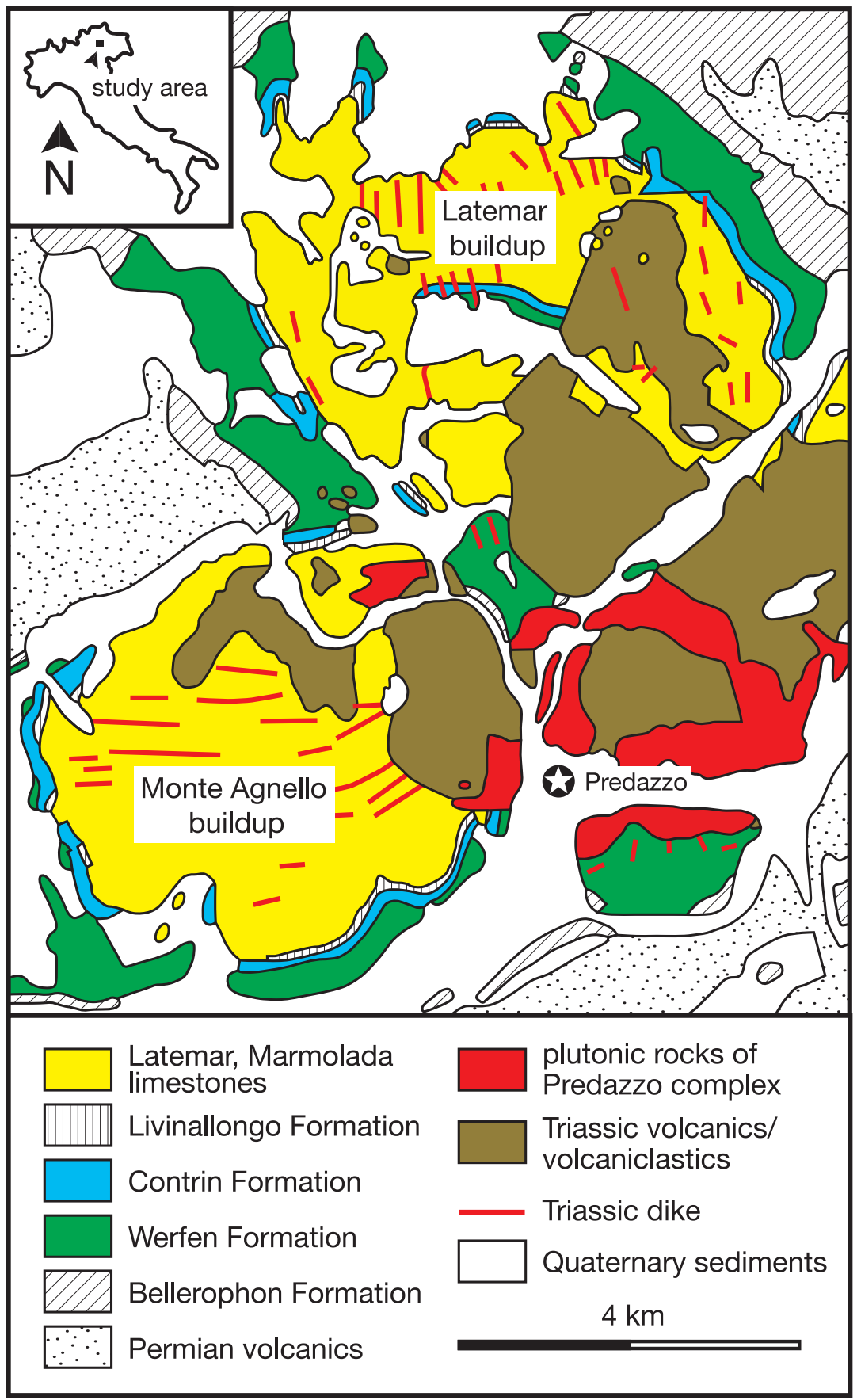

Fig. 1. Geologic sketch map showing the distribution of sedimentary and igneous rocks in the Latemar and Monte Agnello carbonate buildups and adjacent regions (adapted from Leonardi, 1955). The location and thickness of dikes are schematic. Star represents the town of Predazzo. 


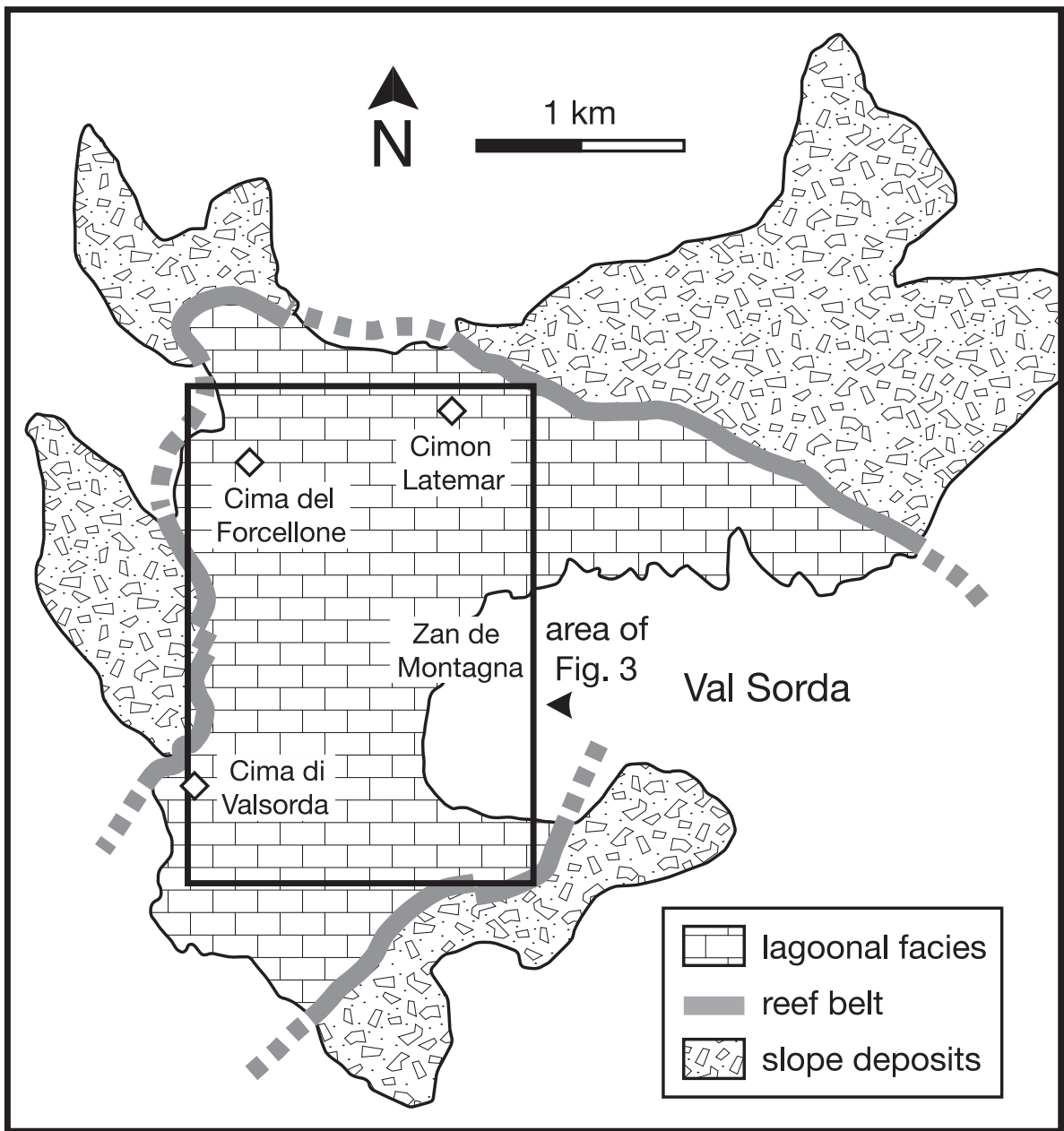

Fig. 2. Distribution of carbonate rock facies within the Latemar carbonate buildup (adapted from Egenhoff and others, 1999). In terms of stratigraphic nomenclature, the lagoonal facies includes the Lower Edifice and the Latemar Limestone, and the reef and foreslope deposits are both assigned to the Marmolada Limestone. The rectangle outlines the area illustrated in figure 3.

the overlying Ladinian Latemar Limestone (350-400 m of nearly flat-lying thinlybedded cyclic grainstones with centimeter-thick dolomite cycle caps that represent repeated subaerial exposure of the platform) (Hardie and others, 1986; Goldhammer and others, 1987, 1990; Preto and others, 2001). The transition between the Lower Edifice and the Latemar Limestone is gradational over a vertical distance of $\sim 50 \mathrm{~m}$. Although not mapped by Egenhoff and others (1999), the Lower Edifice is exposed in a band several hundred meters wide at the eastern margin of the lagoonal facies at the head of Val Sorda. The third stratigraphic unit, the Marmolada Limestone, comprises two sedimentary facies: the reef facies and the foreslope facies, which is composed of breccias and grainstone deposits (fig. 2).

The Predazzo igneous complex was emplaced within, adjacent to, and beneath the Latemar buildup in Middle Triassic time at 232 to $238 \mathrm{Ma}$ (Laurenzi and Visona, 1996; Mundil and others, 1996). The Predazzo complex is composed of a plutonic core 
(mostly monzonite with lesser granite and minor syenite), dikes (leucomonzonite, syenite, and lamprophyre, some of the last of which have been dated at $\sim 234 \mathrm{Ma}$ ), lava flows (that range between alkali olivine basalt and latite), volcaniclastic material, and volcanic breccias containing carbonate rock fragments (Leonardi, 1955; Visona, 1997; Carraro and Visona, 2003). A ring dike complex intruded the Latemar and Monte Agnello buildups (fig. 1), and the southeastern portion of the Latemar buildup was displaced along a caldera fault system (Vardebasso, 1930; Blendinger, 1985). Lavas and volcaniclastic rocks covered the Latemar buildup, filled adjacent basins, and eventually permanently terminated carbonate deposition on the platform and in the surrounding basins.

The Lower Edifice, Latemar Limestone, and Marmolada Limestone have all been partially replaced by dolomite. Based on mutual cross-cutting and inclusion relations between dikes and dolomitized limestone in the field, formation of replacement dolomite is considered contemporaneous with activity of the Predazzo igneous complex (Wilson and others, 1990; Riva and Stefani, 2003).

Although the Dolomites were deformed by folding and thrust faulting during the Tertiary Alpine orogeny, the Latemar buildup and its surrounding region were largely unaffected by Alpine deformation and entirely unaffected by Alpine regional metamorphism (Blendinger, 1985; Doglioni, 1987).

\section{METHODS OF INVESTIGATION}

Two hundred sixty three samples of limestone and dolomite were collected from thirteen outcrops, 1-13, and along six traverses, A-F, (fig. 3). Together they provide information about limestone-dolomite relations at meter to kilometer scales. Dolomitelimestone contacts and sample positions were mapped with decimeter- to centimeterscale accuracy in nine of the thirteen outcrops using a tripod-mounted Laser Technology, Inc., laser rangefinder integrated with a digital fluxgate compass or by tracing digital photographs in the field. Sample locations and contacts among dolomite, limestone, and igneous rocks along the traverses were mapped with the laser rangefinder, a hand-held Magellan GPS device, and a Brunton compass. Locations of all samples are listed in Carmichael (ms, 2006).

Mineral assemblages were determined for 137 samples in polished thin section with back-scattered electron (BSE) imaging using the JEOL JXA-8600 electron microprobe at Johns Hopkins University. Mineral modes and porosity were measured by setting up a $1 \mathrm{~cm}^{2}$ square $4 \times 4$ grid and taking a digital BSE image of the area surrounding each node at $150 \mathrm{X}$ magnification (1024x800 pixels, $0.725 \mu \mathrm{m} / \mathrm{pixel})$. The images were analyzed in Adobe Photoshop by assigning a range of grayscale values to each mineral as well as to porosity. The grayscale values for each mineral and for porosity were determined separately in each sample using the threshold tool. The threshold tool successfully distinguished among oscillatory zoned dolomite, calcite, and porosity. The total number of pixels for each grayscale range was determined using the histogram tool, and the mode of each sample was calculated by summing the number of pixels in each grayscale range in each image. Any uncertainty in mineral identification was resolved by obtaining an energy-dispersive X-ray spectrum. Bright areas of charging or shadows on the surface of the specimen were not included in the pixel sum. Mineral modes and porosity determined in this way agree within error of measurement with modes and porosity obtained by counting 2000 points in thin section using BSE imaging.

Major-element compositions ( $\mathrm{Ca}, \mathrm{Mg}, \mathrm{Fe})$ of calcite and dolomite were measured by wavelength-dispersive X-ray spectrometry with the electron microprobe at Johns Hopkins University using natural mineral standards and a ZAF correction scheme (Armstrong, 1988). Because most samples are nearly monominerallic, minerals were analyzed at the nodes of a $1 \mathrm{~cm}^{2}$ square $4 \times 4$ grid. Additional spots were analyzed as 


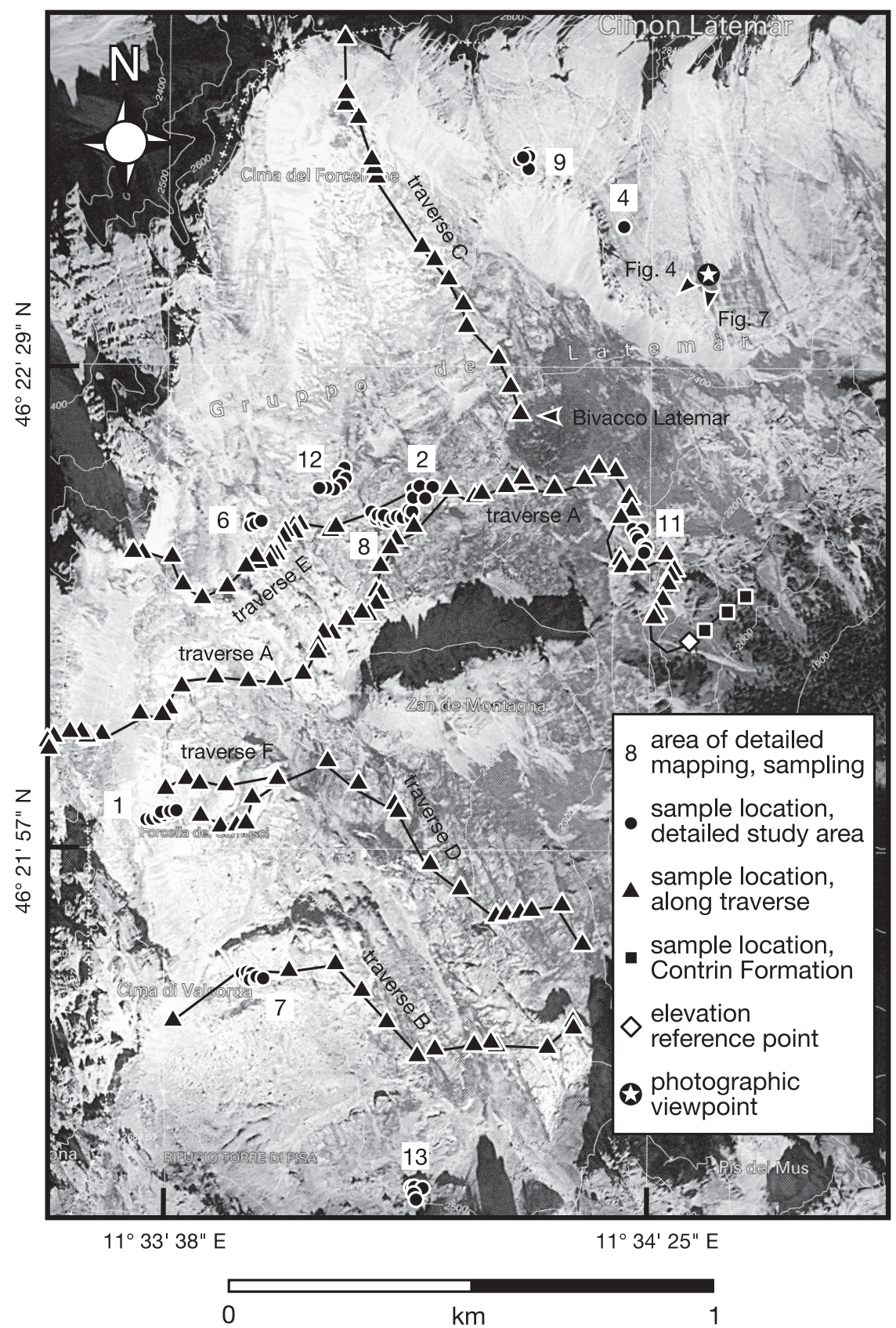

Fig. 3. Orthographic digital aerial photograph of the central portion of the Latemar buildup showing the area of this investigation. Sample locations along each traverse (A-F) are designated by black triangles and connected with thin black lines. Sample locations at each outcrop studied in detail (1-13) are designated by clusters of black circles. Sample locations in the Contrin Formation along traverse A are designated by black squares. The white diamond is the point along the contact between the Contrin Formation and the Lower Edifice that corresponds to normalized $0 \mathrm{~m}$ elevation in figure 12. The star is the location from which photographs in figures 4 and 7 were taken. The faint white grid has 1 kilometer spacing, and faint white curves are elevation contours labeled in meters. 
needed, for example, to characterize the chemical nature of oscillatory zoning in dolomite observed in BSE images.

Carbon and oxygen isotope compositions were analyzed in 239 hand specimens using polished slabs stained for calcite and dolomite. A monominerallic powder was drilled from each slab with a $1-\mathrm{mm}$ or $2-\mathrm{mm}$ diameter diamond-tipped drill. The powders were dissolved in phosphoric acid at $90^{\circ} \mathrm{C}$ for $1000 \mathrm{~s}$, and the released $\mathrm{CO}_{2}$ was purified and analyzed for oxygen and carbon isotope composition with the dual-inlet gas source Micromass Isoprime mass spectrometer in the laboratory of A. J. Kaufman at the University of Maryland. Acid fractionation factors were computed from the expression for dolomite in Rosenbaum and Sheppard (1986) and from the calibration for calcite digested in sealed reaction vessels of Swart and others (1991). Values for $\delta^{18} \mathrm{O}$ and $\delta^{13} \mathrm{C}$ are reported relative to VSMOW and VPDB, respectively. Calcite standards (NBS-19 and Lincoln Limestone, an in-house working standard) were measured multiple times during each analytical session. Analyses of the standards indicate that the analytical precision for both carbon and oxygen isotopes was \pm 0.1 permil $(1 \sigma)$. Duplicate analyses were made of over half the samples. A third analysis was made if the duplicates did not agree within error of measurement, and the average of the two analyses that did agree within error of measurement is reported.

Selected major-, minor-, and trace-element (Ca, Cr, Mn, Fe, Co, Ni, Cu, Zn, Rb, Sr, $\mathrm{Ba}, \mathrm{Pb}$ ) compositions of calcite and/or dolomite were measured in 36 samples using a ThermoFinnigan Element 2 LA-ICPMS coupled to a UP193 (excimer) laser ablation system at the University of Maryland. The mass spectrometer was tuned to maximize signal intensity (based on ${ }^{43} \mathrm{Ca}$ and ${ }^{232} \mathrm{Th}$ spectra) and minimize oxide production $\left({ }^{232} \mathrm{Th}^{16} \mathrm{O} /{ }^{232} \mathrm{Th}<0.20 \%\right)$ while ablating NIST SRM 610 . The NIST-610 silicate glass was used as the primary standard reference material. The spectra for selected major and minor elements $\left({ }^{43} \mathrm{Ca},{ }^{55} \mathrm{Mn},{ }^{57} \mathrm{Fe},{ }^{85} \mathrm{Rb},{ }^{86} \mathrm{Sr},{ }^{88} \mathrm{Sr}\right)$ were first collected with the following laser settings: $\sim 5 \mathrm{~J} \mathrm{~cm}^{-2}, 6-7 \mathrm{~Hz}$, and a 15 to $30 \mu \mathrm{m}$ spot size. Minor and trace element $\left({ }^{53} \mathrm{Cr},{ }^{59} \mathrm{Co},{ }^{61} \mathrm{Ni},{ }^{63} \mathrm{Cu},{ }^{65} \mathrm{Cu},{ }^{66} \mathrm{Zn},{ }^{67} \mathrm{Zn},{ }^{85} \mathrm{Rb},{ }^{86} \mathrm{Sr},{ }^{137} \mathrm{Ba},{ }^{138} \mathrm{Ba},{ }^{206} \mathrm{~Pb},{ }^{208} \mathrm{~Pb}\right)$ spectra were then collected from immediately adjacent locations using the same laser conditions and a 65 to $70 \mu \mathrm{m}$ spot size. Spectral accumulations measured background blank count rates for $\sim 20 \mathrm{~s}$ prior to each ablation followed by $\sim 50 \mathrm{~s}$ of ablation signal. Each mineral in a sample was analyzed in situ in approximately eight pairs of spots within a polished one-inch diameter circular $100-\mu \mathrm{m}$ thick section to control and preserve the petrographic context of the measurements. The spectra obtained from these analyses were processed using LAMTRACE, a Lotus 1-2-3 data reduction spreadsheet (Achterbergh and others, 2001). The spectra for each pair of microsampling spots were analyzed for spikes, trace mineral interferences, breakthrough (when the laser burns through the sample and ablates the underlying glass slide) and background counts. The spectra were averaged over every three cycles of the magnet scan from low to high mass. Anomalous spikes (for example, electronic noise, aberrant noncarbonate materials) in both the background and in the ablation spectra were removed manually. Data for each analysis were processed taking the detection limit as three times the standard deviation of the background. Spectra from different isotopes of the same element (for example, ${ }^{65} \mathrm{Cu}$ and ${ }^{63} \mathrm{Cu}$ ) were compared for each analyzed spot to ensure that the average values obtained were not artificially high due to spectral noise. Only values for the more abundant isotope, however, are reported $\left({ }^{63} \mathrm{Cu},{ }^{66} \mathrm{Zn}\right.$, $\left.{ }^{86} \mathrm{Sr},{ }^{138} \mathrm{Ba},{ }^{208} \mathrm{~Pb}\right)$. Isobaric interferences were monitored and found to be negligible. Major- and minor-element spectra from the first set of analyses were processed using the mineral's average Ca content, previously obtained from microprobe analyses, as the calibration point. The measured ${ }^{86} \mathrm{Sr}$ values from the first set of analyses at each spot were then used to calibrate the second set of minor- and trace-element spectra. 
Element concentrations in the NIST 610 silicate glass standard generally have a 1 to 3 percent uncertainty. Analyses were considered unreliable if the relative standard deviation (RSD) of the glass standard was $>5$ percent for $\mathrm{Mn}, \mathrm{Sr}, \mathrm{Co}, \mathrm{Zn}, \mathrm{Cu}, \mathrm{Ba}, \mathrm{Pb}$, $>6$ percent for $\mathrm{Ni},>7$ percent for $\mathrm{Fe}$, and $>10$ percent for $\mathrm{Cr}$, and the data for that element were then discarded. In some cases, volatilization of calcite samples during previous analyses caused anomalously high mass- 57 backgrounds, making the concentration of ${ }^{57} \mathrm{Fe}$ in the sample appear to be below the detection limit of the instrument. Analyses of $\mathrm{Fe}$ are not reported for samples analyzed under these conditions.

Several samples were imaged by cathodoluminescence using the ELM-3 Luminoscope, and an Olympus Magnafire Imaging System, in the laboratory of Sorena S. Sorensen at the National Museum of Natural History, Smithsonian Institution.

OCCURRENCE AND DISTRIBUTION OF DOLOMITE

\section{Occurrence of Dolomite}

Three types of dolomite occur in the Latemar buildup (Wilson and others, 1990; Schubel, ms, 1997). Cycle cap dolomite occurs as thin (1-15 cm thick) diagenetic caps at the top of units of cyclic carbonate rock in the Latemar Limestone. It is conformable to layering, mostly fine-grained, and has low porosity. Original pore space in the cycle caps is cemented by microsparry dolomite. Saddle dolomite is texturally younger than the cycle cap dolomite and forms coarse-grained cement that fills or partially fills pores, vugs, and veins in the platform carbonates and foreslope deposits. Replacement dolomite is texturally younger than either cycle cap or saddle dolomite. Replacement dolomite is easily distinguished from cycle cap and saddle dolomite in the field because it occurs as much larger bodies with minimum dimensions at least half a meter and, in some cases, up to several tens of meters. Replacement dolomite occurs in the Lower Edifice and the Latemar Limestone as well as in the foreslope deposits. It often cuts across original sedimentary layering. Replacement dolomite usually has a sugary texture that results from a larger grain size than that of cycle cap dolomite, and it has a higher porosity (up to $16 \%$ ) than either cycle cap or saddle dolomite. Together cycle cap and saddle dolomite constitute no more than a few percent of the dolomite exposed in the Latemar buildup (Wilson and others, 1990). Accordingly, the cycle cap and saddle dolomites are not considered further in this study.

\section{Limestone-Dolomite Contacts}

Replacement dolomite is primarily distinguished from limestone in the field on the basis of color (fig. 4). Limestone is white, very pale gray, or pale cream color. Replacement dolomite is tan or orange because of elevated Fe and $\mathrm{Mn}$ contents relative to limestone. Furthermore, some but not all dolomite has elevated porosity (up to $16 \%$ ) relative to limestone $(<9 \%$ and typically $\sim 3 \%$ or less). In addition, replacement dolomite often has a sugary texture because of larger grain size compared to limestone. Contacts between limestone and dolomite were mapped in the field based on these differences between the two rock types.

Most analyzed samples of limestone are 100 percent calcite or nearly so, and most samples of dolomite are 100 percent dolomite or nearly so (table 1, fig. 5), implying sharp limestone-dolomite contacts. Occurrences of limestone with $\geq 20$ percent dolomite (for example, samples 8E and 8P, fig. 5) and of dolomite with $>20$ percent calcite (for example, sample 8-1, fig. 5) are restricted to regions within a few tens of centimeters of mapped limestone-dolomite contacts. The sharpness of dolomitelimestone contacts was documented in greater detail at the lower and upper sides of a nearly horizontal, tabular dolomite body at location 8 (fig. 6). On the lower side of the body, where samples better constrain the sharpness of the contact, the separation between limestone with $<5$ percent dolomite (sample $8 \mathrm{~B}$ ) and dolomite with $<2$ 


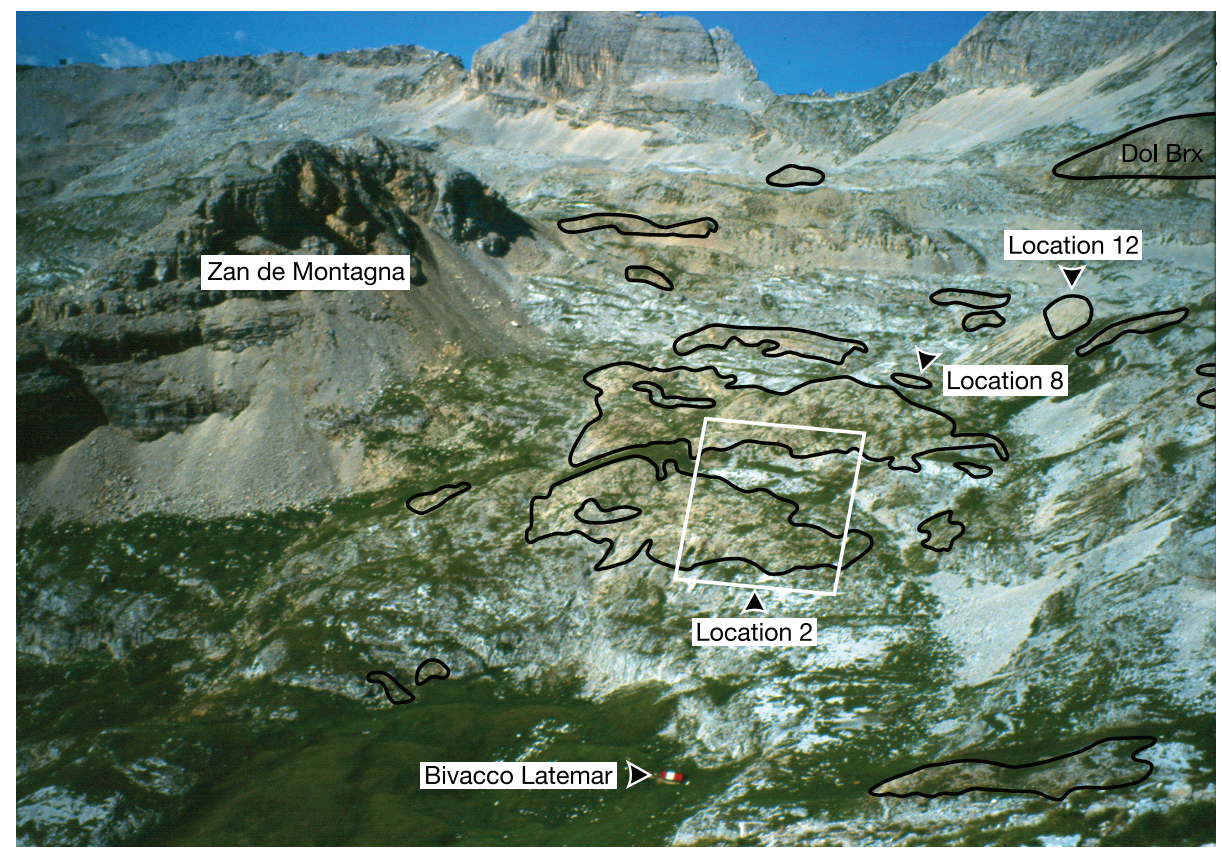

Fig. 4. Panoramic view of the interior of the Latemar buildup taken from the photographic viewpoint in figure 3 looking southwest. The field of view is $\sim 1 \mathrm{~km}$ wide in the foreground and $\sim 2 \mathrm{~km}$ wide on the skyline. Topographic relief between foreground and skyline is $\sim 500 \mathrm{~m}$. The photograph illustrates the distinctive difference in color between tan and orange replacement dolomite (bodies outlined in black) and pale gray or white limestone. All outlined dolomite bodies were verified by direct examination on the ground. Dolomite bodies were not mapped on Zan de Montagna because of the confusing affects of shadow and talus cover. Other orange areas are either covered by dolomite talus or expose limestone with an unusual pale orange weathering surface. Numbers identify locations 12, 8, and 2 illustrated in more detail in figures 8,9 , and 10, respectively. "DolBrx" identifies an exposure of dolomite breccia not mapped in detail.

percent calcite (sample $8 \mathrm{Q}$ ) is $20 \mathrm{~cm}$ perpendicular to the limestone-dolomite contact. In samples, like $8 \mathrm{E}$ and $8 \mathrm{P}$ (fig. 6 ), that contain significant amounts of both calcite and dolomite, dolomite occurs in a network of veinlets set in a matrix of unaltered limestone. Limestone-dolomite contacts are sharp at the outcrop and larger scales regardless of the geometry or orientation of the dolomite body.

\section{Geometry of Replacement Dolomite Bodies}

A panoramic view of the interior of the Latemar buildup, from the vantage point of the starred location in figure 3 looking southwest, documents that replacement dolomite occurs in heterogeneously distributed but well-defined bodies of a variety of sizes (fig. 4). The dolomite bodies occur in the vertical dimension between the base of the Lower Edifice and the highest elevation visited, the top of Forcella Latemar Picola, $870 \mathrm{~m}$ above. Although not easily discerned in figure 4, dolomite bodies occur in several distinct geometries.

Dolomite bodies bounded primarily by vertical contacts. - Dolomite bodies with primarily vertical or nearly vertical contacts occur in both the Lower Edifice and the Latemar Limestone. The most common form is a vertical column with a diameter of several tens of meters and a height of at least $100 \mathrm{~m}$ (fig. 7). Where accessible to close examination and outcrop-scale mapping, the columns are breccias composed of blocks of both dolomite and unaltered limestone, several decimeters to several meters in diameter, set in an undeformed dolomite matrix (for example, location 12, fig. 8). Rocks in the 
TABLE 1

Modes for selected samples of limestone and dolomite

\begin{tabular}{cclrrcc}
\hline $\begin{array}{c}\text { Location or } \\
\text { Traverse }\end{array}$ & Sample & Rock Type & Calcite & Dolomite & Porosity & $\begin{array}{c}\text { Accessory } \\
\text { Minerals }\end{array}$ \\
\hline \hline 1 & $\mathrm{~A}$ & limestone & 98.93 & 0.42 & 0.85 & 0.06 \\
1 & $\mathrm{C}$ & orange dolomite & 1.28 & 92.75 & 6.10 & 0.04 \\
8 & $\mathrm{~A}$ & limestone & 96.26 & 1.02 & 2.76 & 0.03 \\
8 & $\mathrm{~B}$ & limestone & 94.55 & 3.31 & 2.23 & 0.09 \\
8 & $\mathrm{C}$ & tan dolomite & 1.22 & 93.84 & 4.98 & 0.00 \\
8 & $\mathrm{D}$ & tan dolomite & 1.72 & 88.98 & 9.44 & 0.00 \\
8 & $\mathrm{E} *$ & limestone & 75.44 & 21.89 & 3.11 & 0.05 \\
8 & $\mathrm{~F}$ & limestone & 96.99 & 0.35 & 2.68 & 0.17 \\
8 & $\mathrm{P} *$ & limestone & 78.94 & 19.61 & 1.54 & 0.07 \\
8 & $\mathrm{Q} *$ & tan dolomite & 1.23 & 92.40 & 6.52 & 0.02 \\
8 & 9 & tan dolomite & 2.78 & 80.90 & 16.41 & 0.00 \\
$\mathrm{~A}$ & 1 & limestone & 94.95 & 2.20 & 2.92 & 0.03 \\
$\mathrm{~A}$ & 17 & limestone & 97.50 & 0 & 2.74 & 0.04 \\
$\mathrm{~A}$ & 34 & tan dolomite & 2.48 & 90.68 & 6.98 & 0.00 \\
$\mathrm{~A}$ & 43 & orange dolomite & 0.01 & 90.54 & 9.58 & 0.00 \\
$\mathrm{~A}$ & 44 & limestone & 91.43 & 6.97 & 1.84 & 0.01 \\
$\mathrm{~A}$ & 51 & tan dolomite & 0 & 96.94 & 3.14 & 0.01 \\
\hline
\end{tabular}

Values in volume percent.

*Samples that are in the narrow transition zone between limestone and dolomite.

${ }^{\dagger}$ Combinations of K-feldspar, iron oxide, pyrite, quartz, apatite, rutile, zircon, biotite, gypsum or anhydrite, ilmenite, sphalerite, fluorite, and monazite.

breccia columns are not mylonitized. The contact between the breccia column and adjacent limestone wall rock is sharp but highly irregular. Riva and Stefani (2003) conclude that the breccias were produced by extension caused by emplacement of the Predazzo igneous complex. Elsewhere in the Dolomites, similar breccia columns are considered to have developed prior to dolomitization (Zempolich, ms, 1995; Zempolich and Hardie, 1997). The occurrence of undeformed dolomite between blocks is consistent with formation of breccia columns prior to dolomitization in the Latemar buildup as well. The breccias presumably were favorable pathways for later flow of dolomitizing fluid.

Although less common, bodies of replacement dolomite with vertical contacts also occur as vertical or nearly vertical tabular bodies. Detailed examination of these bodies indicates that the replacement dolomite typically developed adjacent to vertical or nearly vertical fractures (fig. 9A). Less commonly, tabular dolomite bodies developed along the vertical contact between limestone and dikes emplaced prior to dolomitization (for example, Fig. 9 of Wilson and others, 1990). The initial contact between dike and limestone appears to have been more permeable to dolomitizing fluids than limestone away from the contact.

Dolomite bodies bounded primarily by horizontal contacts. - Dolomite bodies with primarily horizontal or nearly horizontal contacts are almost entirely restricted to the Latemar Limestone. Most commonly they form tabular bodies that are exactly parallel or nearly parallel to bedding, although replacement dolomite may cut across bedding locally at 


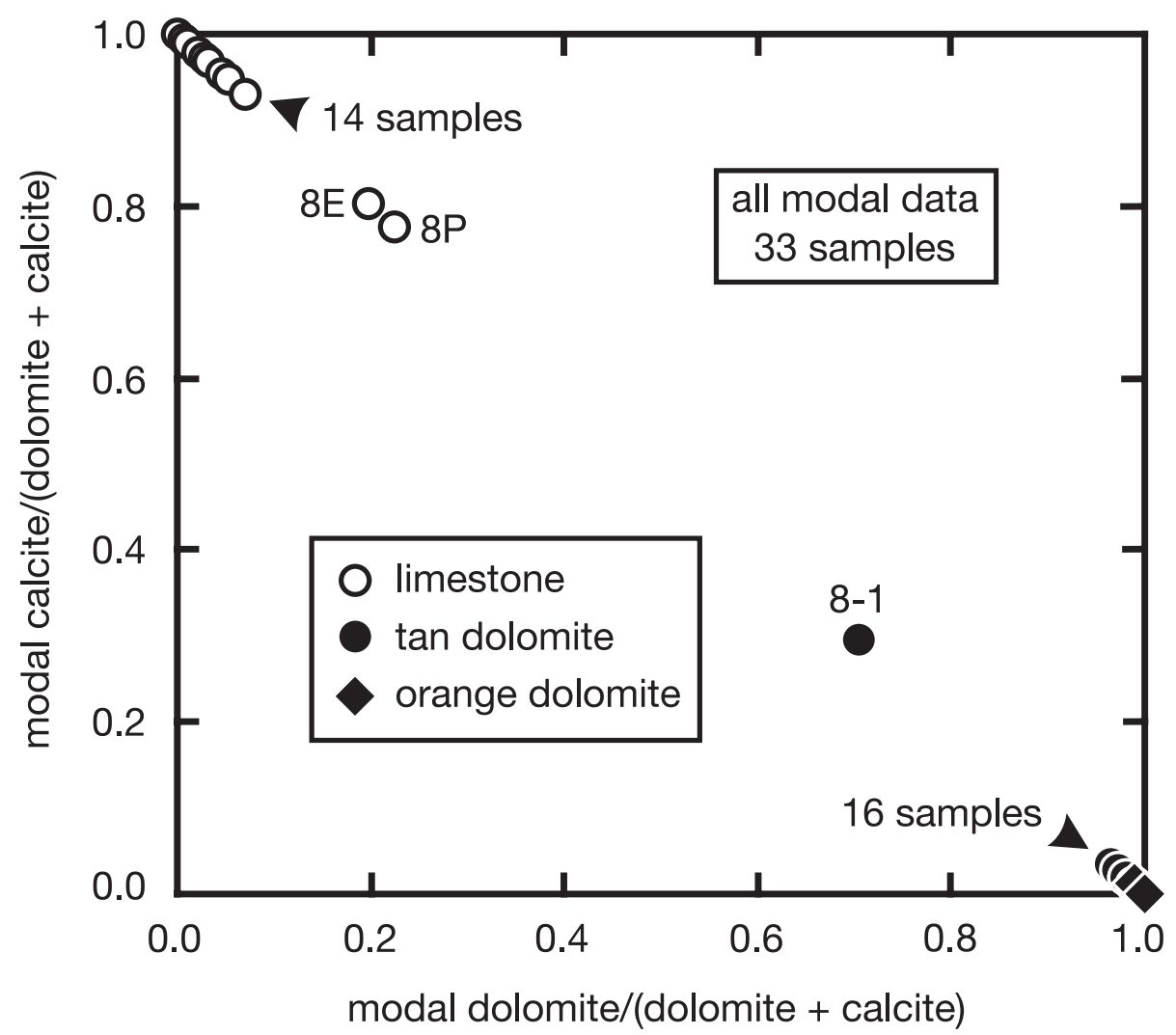

Fig. 5. Relative modal proportions of calcite and dolomite in all analyzed samples of limestone and replacement dolomite from the Latemar buildup. The paucity of limestone samples with $>10$ relative percent dolomite and of dolomite samples with $<95$ relative percent dolomite reflects sharp limestonedolomite contacts in the field. Samples $8 \mathrm{E}, 8 \mathrm{P}$, and $8-1$ were collected within $\sim 20 \mathrm{~cm}$ of a limestone-dolomite contact (see fig. 6).

the centimeter scale. On vertical or steeply dipping exposures, the sheets of dolomite appear as fingers, several decimeters to several meters thick, extending up to several tens of meters along bedding horizons (for example at locations 7 and 8, fig. 9). Two bedding-parallel sheets of replacement dolomite are exposed at location 2 over a topographic surface that cuts across bedding at a very small angle (fig. 10). Layer 1 is additionally exposed in karst solution pits that penetrate the intervening limestone layer (inliers, fig. 10). The western limit of layer 1 in map view is defined by its stratigraphic contact with the overlying limestone layer; its eastern limit is where the dolomitized layer has been truncated by erosion on its downhill side. The directly measured thickness of layer 1 is $3.3 \mathrm{~m}$. The exposure of layer 1 in figure 10 demonstrates that bedding-parallel sheets of replacement dolomite indeed have horizontal dimensions that are large $\left(>10,000 \mathrm{~m}^{2}\right)$ compared to their thickness $(\sim 3 \mathrm{~m})$.

Replacement dolomite also occurs on vertical or steeply dipping exposures of the Latemar Limestone as isolated pods that often line up along a single bedding plane (fig. 9A). In some cases, a string of pods is aligned with a tabular body of replacement dolomite exposed in cross-section along the same bedding plane (fig. 9A). The isolated dolomite pods therefore are interpreted as cross-sections through tubular bodies that are confined to specific bedding horizons. The tubes may represent finger-like extensions of the bedding-parallel tabular bodies of replacement dolomite. 


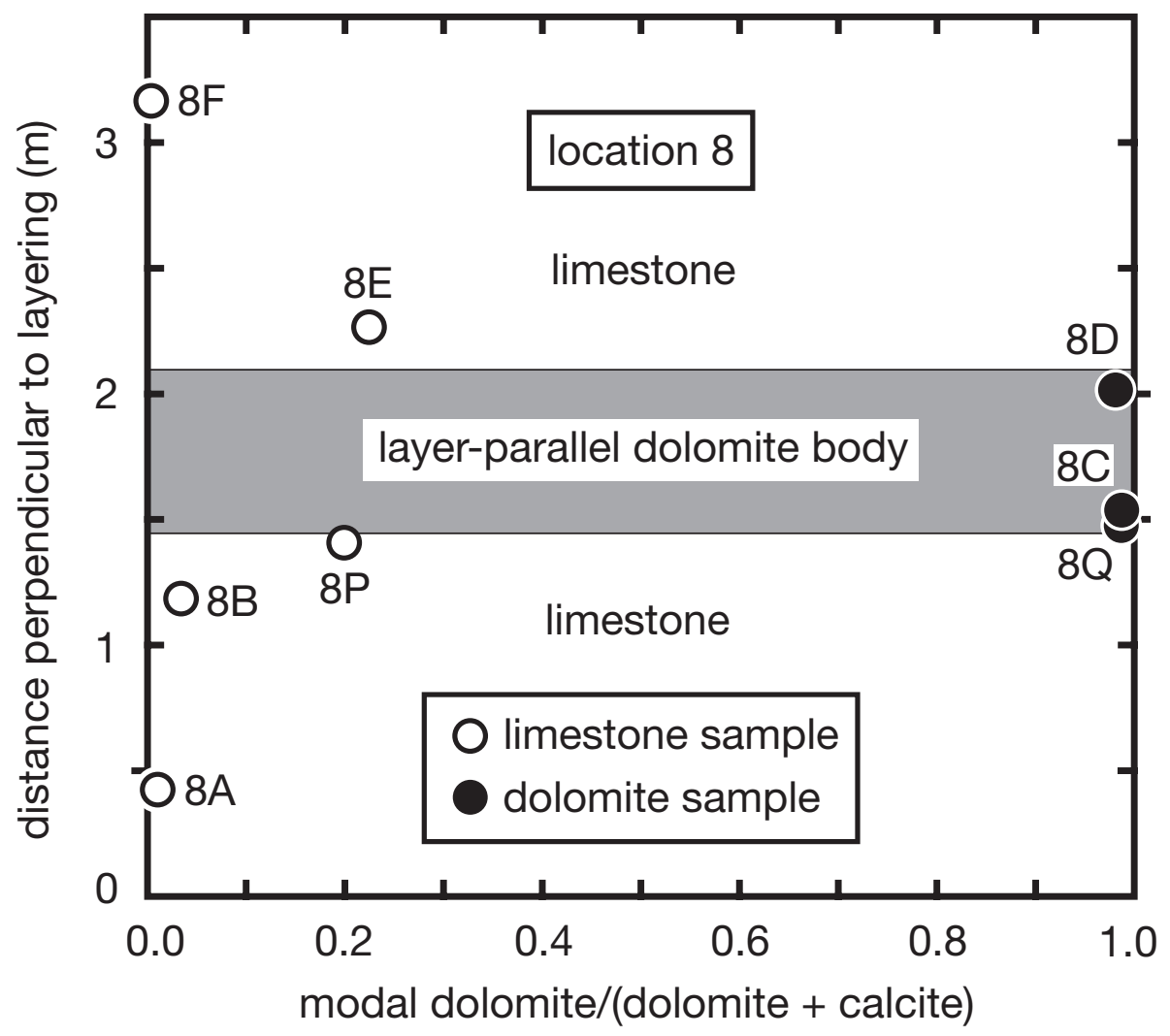

Fig. 6. Profile in relative modal proportions of calcite and dolomite across a tabular bedding-parallel body of replacement dolomite at location 8 . The ordinate represents distance across the outcrop perpendicular to bedding. Sample positions (fig. 9B) have been projected along bedding to the common distance coordinate. The data demonstrate that the transition between unaltered limestone and replacement dolomite occurs over a distance $<20 \mathrm{~cm}$ perpendicular to the contact.

Where bedding-parallel tabular bodies of replacement dolomite are exposed connected to vertical tabular bodies (fig. 9A), the bedding-parallel tabular bodies are preferentially developed on the up-dip side of the vertical bodies.

Irregularly-shaped bodies of replacement dolomite.-Bodies of replacement dolomite on steeply-dipping exposures of the Latemar Limestone also may form a network that is more irregular than the shapes illustrated in figures 9 and 10 (for example, location 13, fig. 11). Nevertheless, even the more irregularly shaped bodies roughly conform to the overall geometry of horizontal or nearly horizontal bedding parallel sheets and tubes interconnected with vertical or nearly vertical sheets or tubes.

\section{Vertical Distribution of Rock Types and Types of Contacts}

Distribution of rock types. - The relative proportions of limestone and replacement dolomite were measured along six traverses (A-F, fig. 3) over a total distance of $9.7 \mathrm{~km}$. The position of every contact between limestone or dolomite and any other rock type along each traverse was projected parallel to bedding (using a single representative strike and dip of bedding in the Latemar buildup, $330^{\circ}$ and $10^{\circ} \mathrm{E}$ ) to an arbitrarily chosen point at the contact between the Contrin Formation and the Lower Edifice (white diamond, fig. 3) and the elevation recorded. Data from all traverses were 


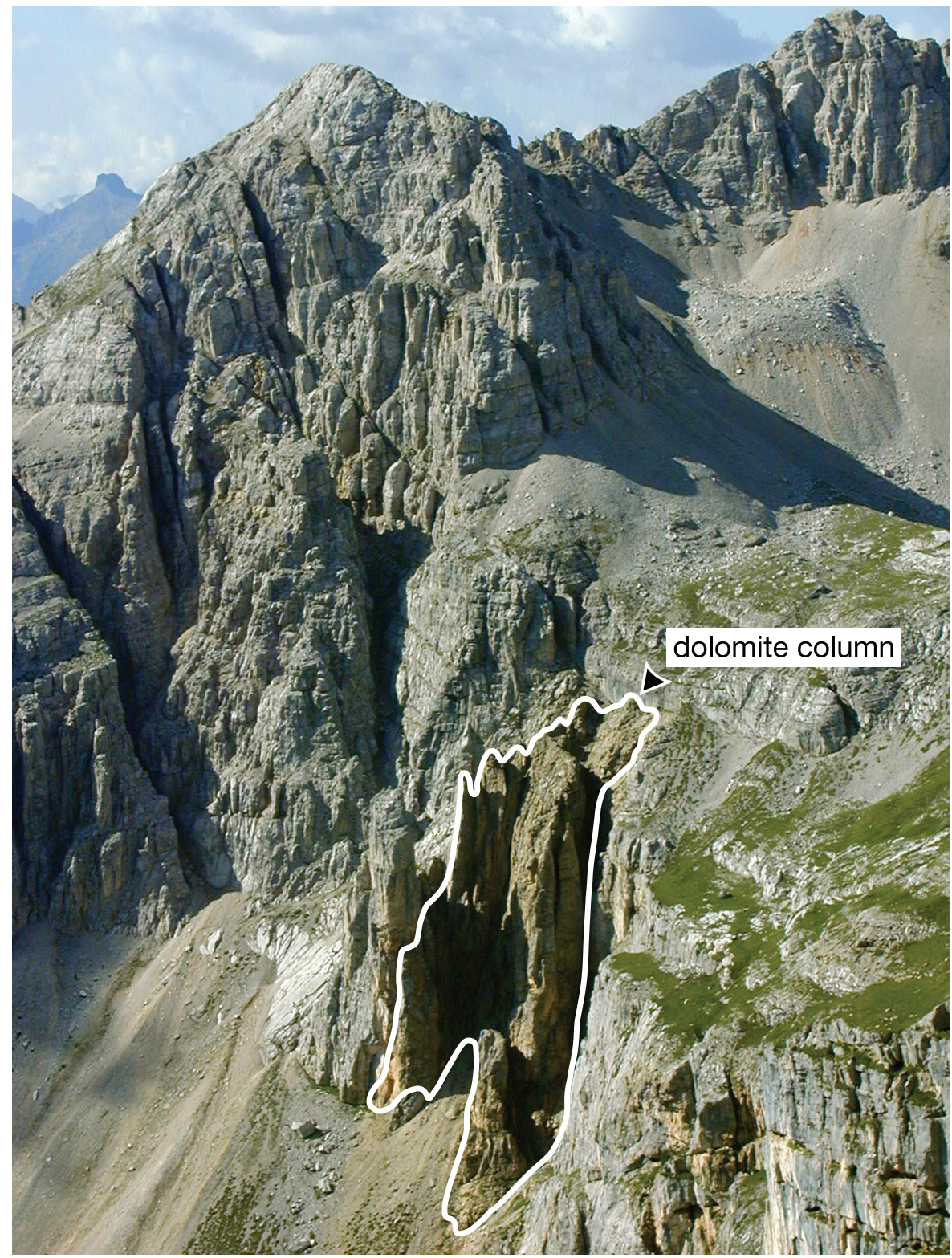

Fig. 7. Panoramic view of a column of dolomite breccia (outlined in white) exposed in the Lower Edifice taken from the photographic viewpoint in figure 3 looking south. The exposed portion of the column is $\sim 40 \mathrm{~m}$ in diameter and $\sim 150 \mathrm{~m}$ high.

combined, and the cumulative relative proportions of limestone and dolomite as a function of vertical distance above the Contrin-Lower Edifice contact are illustrated in figure 12A. The curves in figure 12A are normalized to the total cumulative amount of limestone plus dolomite measured along the traverses between the lowest and the highest elevations studied. The right-hand ends of the curves therefore give the average relative proportion of dolomite $(0.35)$ and limestone $(0.65)$ as a whole over 


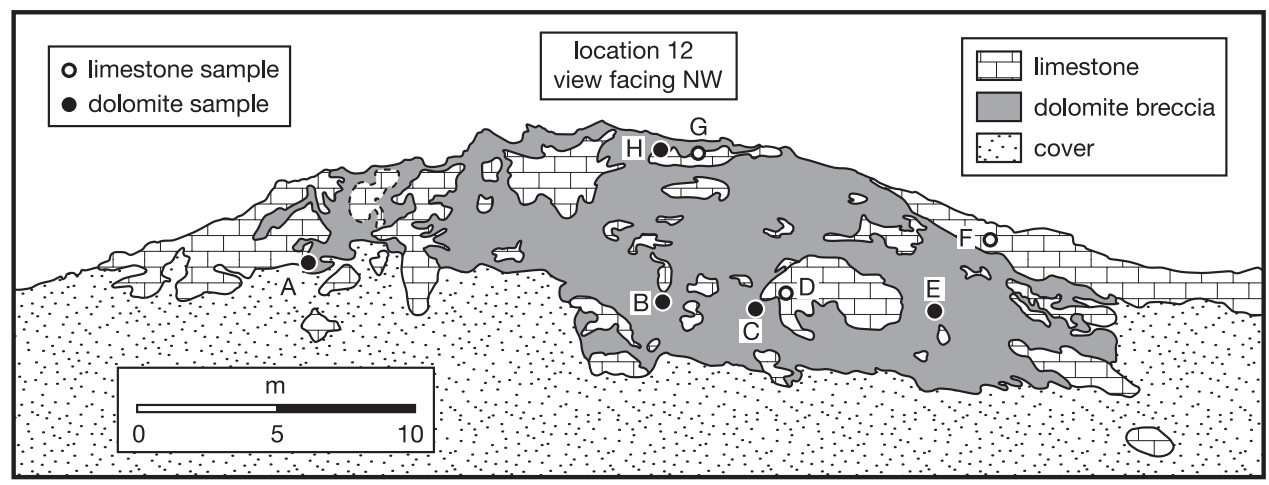

Fig. 8. Map of dolomite breccia exposed on a steep slope at location 12 (figs. 3 and 4) traced from a digital photograph. The breccia is composed of blocks of tan replacement dolomite and unaltered limestone set in a matrix of tan dolomite. Contacts are dashed where approximate. Exposure of the breccia in map view is approximately circular. All outlined limestone blocks were verified by direct examination in the field.

the area investigated in detail. The curves below $\sim 120 \mathrm{~m}$ in figure $12 \mathrm{~A}$ are not representative because that portion of the Latemar buildup is inaccessible (fig. 7) except along a single trail that happens to lie entirely within either replacement dolomite or cover. Both limestone and replacement dolomite occur along each of the traverses. Data in figure 12A document that the amount of dolomite relative to limestone decreases with elevation. At the highest elevations where measurements were made, exposures of dolomite are rare, indicated by the steep slope of the curve for limestone above $600 \mathrm{~m}$ in figure 12A.

Distribution of vertical and horizontal contacts. - The location and orientation of every limestone-dolomite contact were recorded over the aggregate distance of $9.7 \mathrm{~km}$ along traverses A-F in figure 3. Because limestone-dolomite contacts are usually horizontal (or nearly so) or vertical (or nearly so), each measurement was designated as either horizontal or vertical. The cumulative relative proportions of horizontal and vertical contacts as a function of elevation above the Contrin-Lower Edifice contact are illustrated in figure 12B. The curves in figure 12B are normalized to the total cumulative number of vertical plus horizontal contacts counted along the traverses between the lowest and the highest elevations studied. The right-hand ends of the curves therefore give the average relative proportion of vertical $(0.57)$ and horizontal (0.43) contacts as a whole over the area investigated in detail. The curves initiate at $\sim 120 \mathrm{~m}$ because both the Contrin Formation and the Lower Edifice are entirely composed of dolomite where measurements could be made below $120 \mathrm{~m}$. Data in figure 12B document that almost all limestone-dolomite contacts in the Lower Edifice are vertical. Both vertical and horizontal contacts occur in the Latemar Limestone.

\section{Overall Geometry of Replacement Dolomite in the Latemar Carbonate Buildup}

The shape of dolomite bodies mapped in figures 7-11 and the distribution of rock types and contact types illustrated in figure 12 lead to generalizations about the occurrence of replacement dolomite in the Latemar buildup (fig. 13). On the scale of the entire buildup replacement dolomite appears to have developed in a nearly orthogonal lattice of vertical or nearly vertical columns and sheets (corresponding to breccia columns and to fractures or dike-limestone contacts, respectively) connected to horizontal or nearly horizontal bedding-parallel sheets and tubes (corresponding to dolomite formed along specific bedding planes). Vertical dolomite breccia columns occur at all levels, and are exposed from the base of the Lower Edifice to the tops of the 

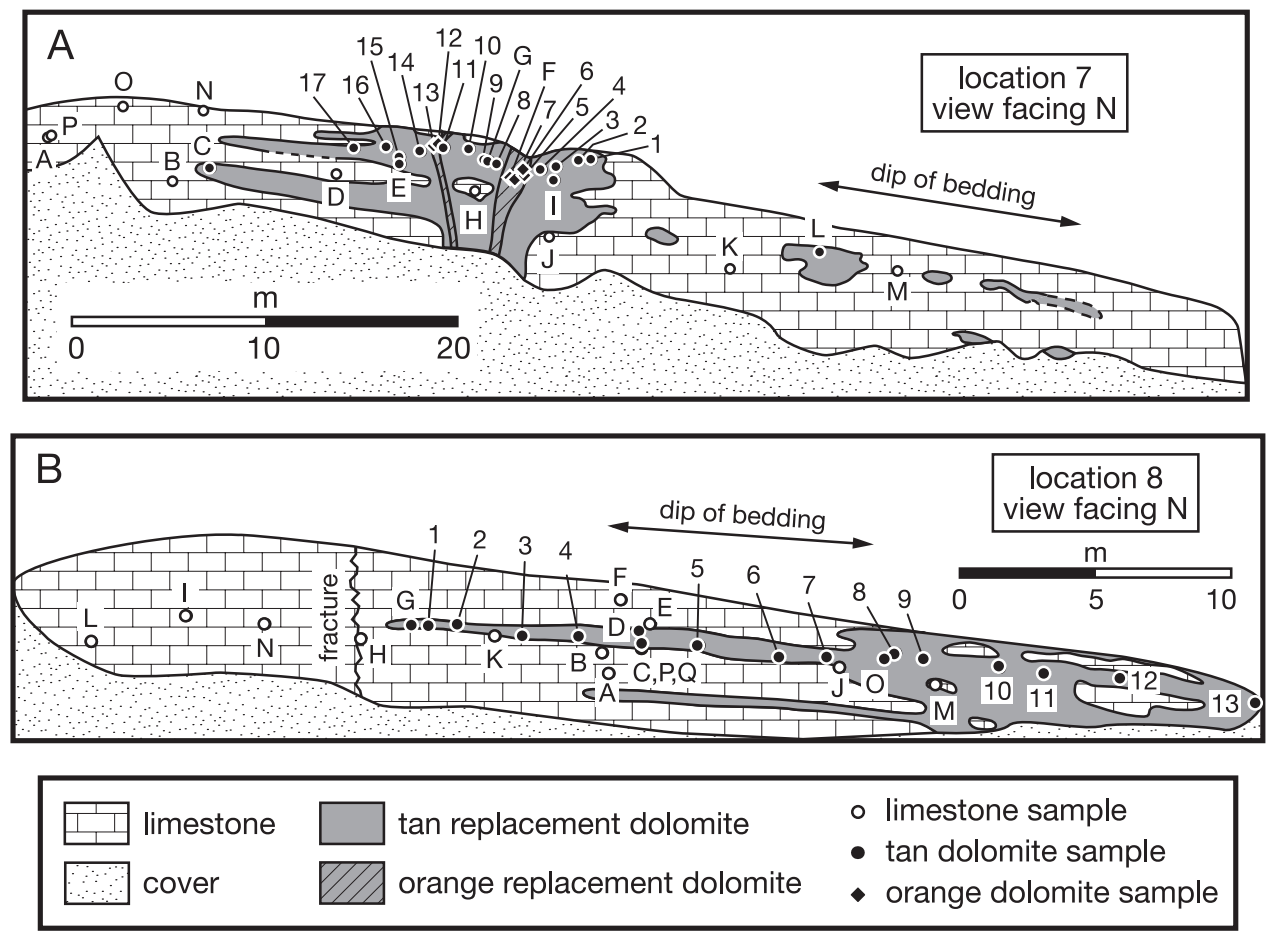

Fig. 9. Map of relations between limestone and replacement dolomite exposed on steep south-facing slopes at locations 7 (A) and 8 (B) (figs. 3 and 4) made using a tripod-mounted laser rangefinder integrated with a digital fluxgate compass. Contacts are dashed where approximate. All contacts and sample locations have been projected along horizontal north-south lines to a vertical plane that strikes east-west. Layerparallel bands of tan dolomite are cross sections through layer-parallel tabular bodies. Isolated pods of tan dolomite are cross sections through layer-parallel tubular bodies. Nearly vertical bands of orange dolomite are cross sections through nearly vertical sheets with fractures at their centers. Layer-parallel sheets of replacement dolomite are preferentially developed at location 7 on the up-dip side of their connection to the vertical sheets of orange dolomite.

highest peaks. Significant numbers of layer-parallel sheets and tubes, however, are restricted to the lower third of the Latemar Limestone. The much greater development of layer-parallel dolomite bodies in the Latemar Limestone, compared to the Lower Edifice, appears to have been controlled by original sedimentary structures. The Lower Edifice is composed of relatively thick beds, and bedding is not well defined. In contrast, the Latemar Limestone is composed of thin, relatively well-developed beds.

\section{MINERALOGY, MINERAL TEXTURES, AND MINERAL CHEMISTRY}

\section{Mineralogy and Mineral Textures}

Modes of representative samples of limestone and replacement dolomite are listed in table 1; modal data for all analyzed samples are compiled in Carmichael (ms, 2006). Except within $\sim 20 \mathrm{~cm}$ of limestone-dolomite contacts, limestone is $>90$ percent calcite (fig. 14A) and dolomite is $>90$ percent dolomite (fig. 14B). Modal variability in limestone and dolomite is principally due to porosity and either isolated grains of dolomite (in limestone) or of calcite (in dolomite). Other minerals, including Kfeldspar, Fe oxide, pyrite, quartz, apatite, rutile, zircon, biotite, gypsum or anhydrite, ilmenite, sphalerite, fluorite, and monazite, occur in trace quantities and their combined modes rarely exceed 0.2 percent. Euhedral K-feldspar (fig. 14A), quartz, 


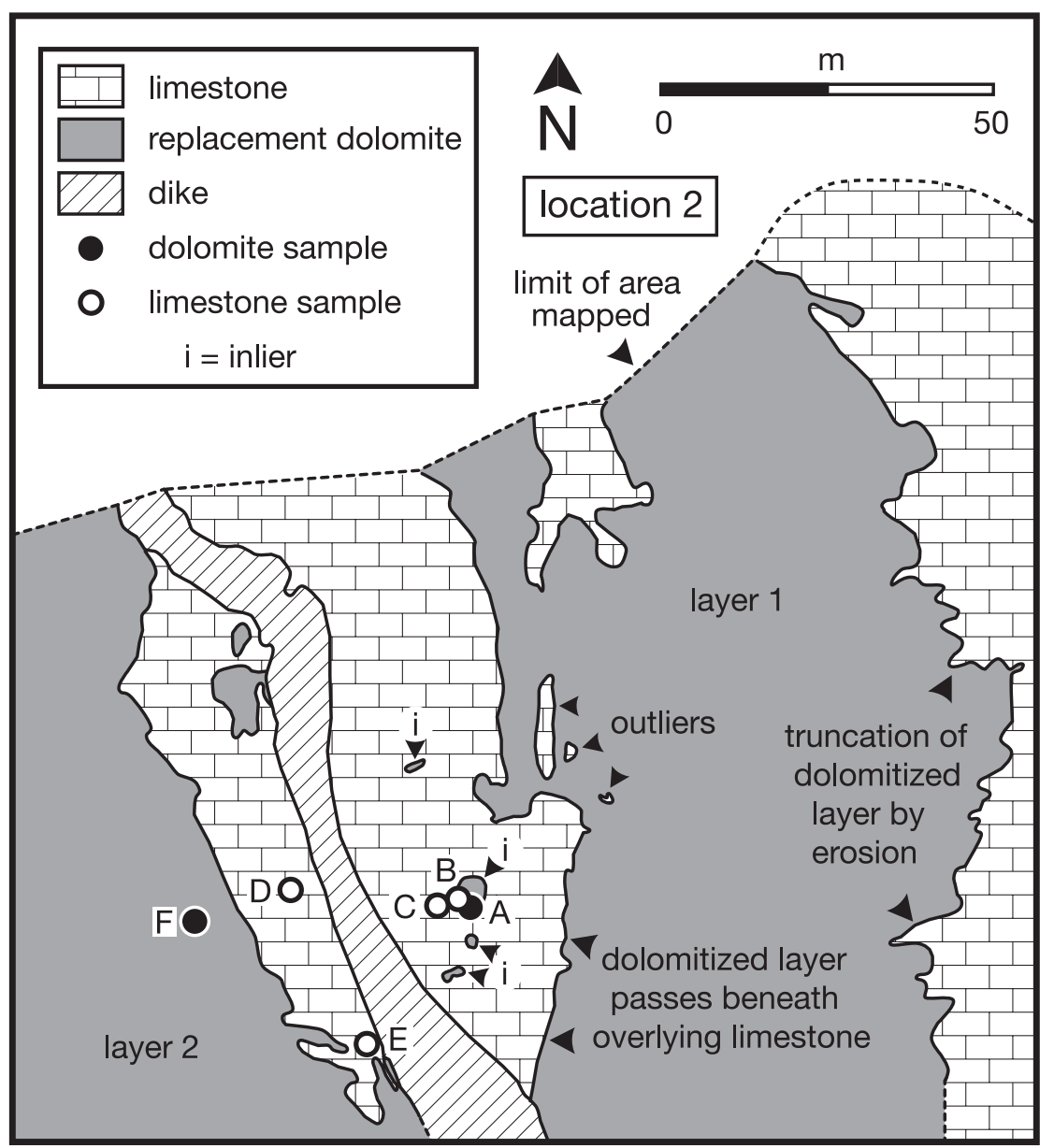

Fig. 10. Map of relations between limestone and replacement dolomite exposed on a topographic surface that cuts across bedding at a very small angle at location 2 (figs. 3 and 4) made using a tripod-mounted laser rangefinder integrated with a digital fluxgate compass. Contacts are dashed where approximate. A tabular, bedding-parallel body of replacement dolomite, layer 1, lies beneath layer 2 and is separated by a layer of limestone. Considering its exposure on the surface and in karst pits that penetrate the overlying limestone layer, the area of layer 1 is $>10,000 \mathrm{~m}^{2}$, demonstrating that layer-parallel tabular bodies of replacement dolomite have horizontal dimensions much greater than their thickness (layer 1 is $3.3 \mathrm{~m}$ thick by direct measurement).

and pyrite, and anhedral Fe oxide and dolomite in limestone (fig. 14A) are believed to have developed during diagenesis or during formation of replacement dolomite. Rutile, zircon, biotite, ilmenite, and monazite typically occur as rounded detrital grains. Dolomite grains commonly contain minute calcite inclusions (fig. 14B) interpreted as remnants of calcite that escaped replacement by dolomite. Although there is considerable overlap, analyzed dolomites as a group contain more porosity $(3.1-16.4 \%$, most $>6 \%)$ than do analyzed limestones $(0.9-8.8 \%$, most $\sim 3 \%$ or less). Calcite in limestone appears uniform in BSE images (fig. 14A) while many dolomite grains display pronounced oscillatory zoning (fig. 14B). The same kind of oscillatory zoning in dolomite illustrated in figure 14B is observed in cathodoluminescence (Carmichael, ms, 2006). 


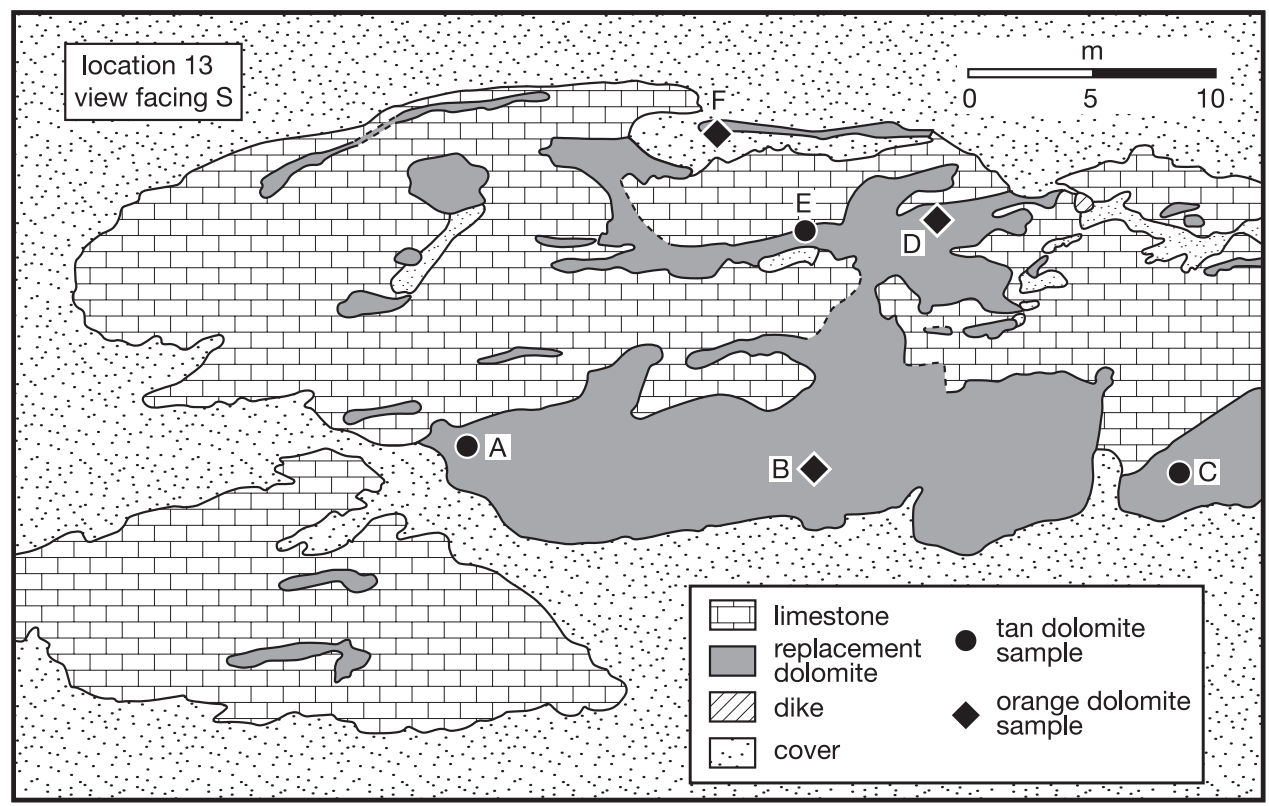

Fig. 11. Map of more irregularly shaped bodies of replacement dolomite exposed on a steep northfacing slope at location 13 (fig. 3) traced from a digital photograph. Contacts are dashed where approximate.

\section{Mineral Chemistry}

Major-, minor-, and trace-element analyses of calcite and of dolomite in representative samples of limestone and replacement dolomite are listed in table 2; compositions of all analyzed minerals are compiled in Carmichael (ms, 2006).

Major-element mineral chemistry.-Analyzed calcite in limestone is almost pure $\mathrm{CaCO}_{3}$ with 0.98 to $0.99 \mathrm{Ca}$ atoms per formula unit (pfu), 0.01 to $0.02 \mathrm{Mg}$ atoms pfu, and $<0.01$ atoms pfu all other elements combined (table 2). Replacement dolomite has more variable composition with 1.01 to $1.10 \mathrm{Ca}$ atoms pfu, 0.88 to $0.99 \mathrm{Mg}$ atoms pfu, between $<0.01$ and $0.07 \mathrm{Fe}$ atoms pfu, and $<0.01$ atoms pfu all other elements combined. Tan and orange replacement dolomites are observed in the field (fig. 9A and fig. 11), and the difference in color appears to result from a difference in Fe content. Tan dolomite averages $0.01 \mathrm{Fe}$ atoms pfu while orange dolomite averages 0.03 Fe atoms pfu. There is no significant difference in major-element composition between dolomite from breccia columns and tan replacement dolomite from other occurrences. The pronounced oscillatory zoning in dolomite observed in BSE imaging (fig. 14B) is explained by zoning in Fe (fig. 15). Electron microprobe analyses along one traverse across the zoning, document that the Fe content of individual zones varies between 0.002 and 0.016 atoms pfu. Transmission electron microscopy reveals that dolomites with elevated Ca are partly disordered (Schubel, ms, 1997).

Minor- and trace-element mineral chemistry.- -Analyzed calcite in limestone and replacement dolomite can contain concentrations of $\mathrm{Fe}, \mathrm{Mn}, \mathrm{Sr}, \mathrm{Cr}, \mathrm{Co}, \mathrm{Ni}, \mathrm{Cu}, \mathrm{Zn}, \mathrm{Ba}$, and $\mathrm{Pb}$ above detection limits (table 2). The concentration of each of these elements was plotted against that of Mn, as justified in Part 2, because Mn is the element most likely conserved during mixing of high-temperature mid-ocean ridge hydrothermal vent fluids with seawater (Von Damm and Lilley, 2004). The various minor and trace 

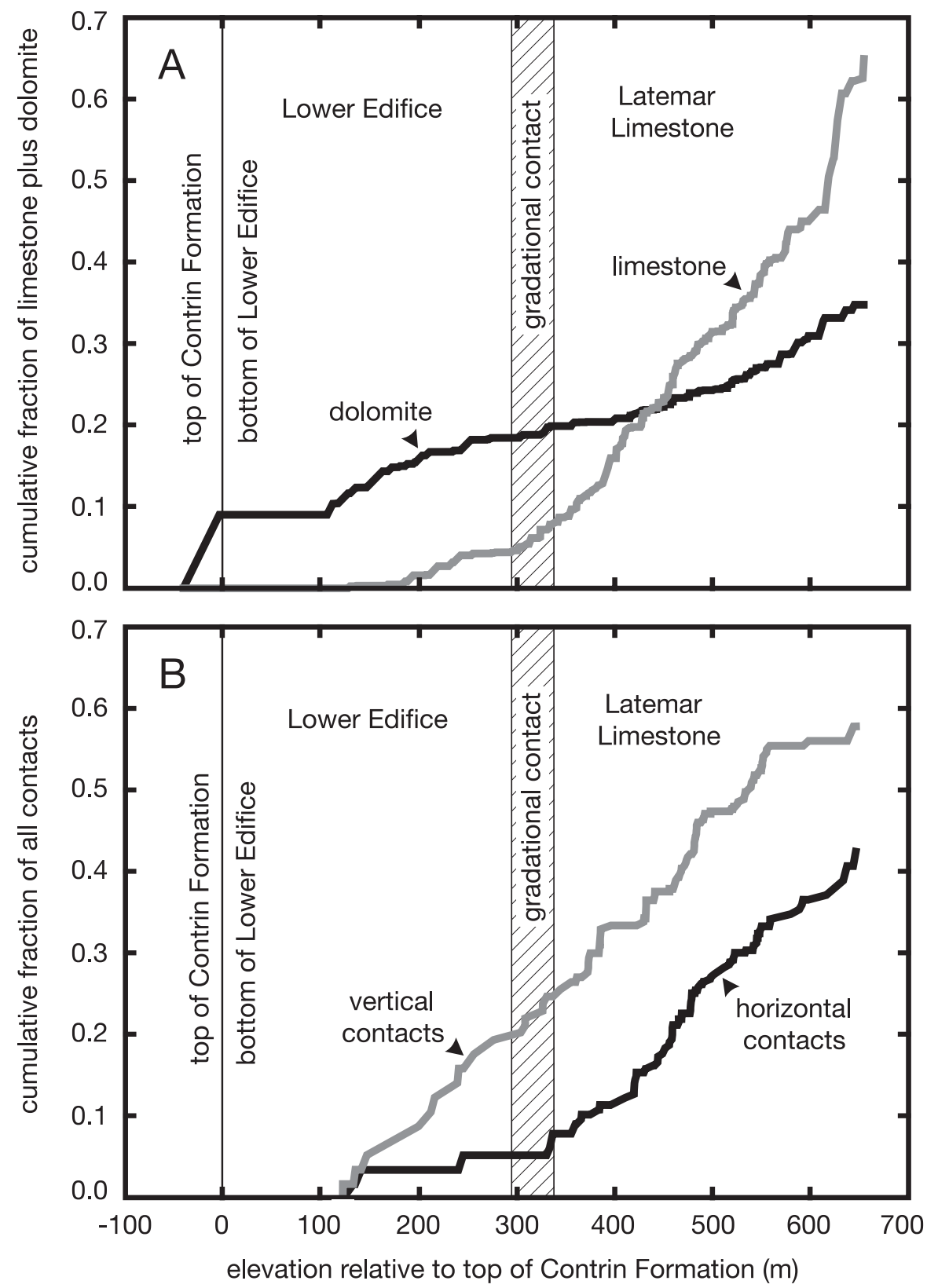

Fig. 12. Cumulative fractions of limestone and dolomite (A) and of vertical and horizontal limestonedolomite contacts (B) as a function of elevation. Curves in panel (A) are normalized to the total cumulative amount of limestone plus replacement dolomite between the lowest and highest elevations studied. Curves in panel (B) are normalized to the total cumulative number of vertical plus horizontal contacts recorded between the lowest and highest elevations studied. Cumulative curves were compiled from data collected over $9.7 \mathrm{~km}$ along traverses A-F (fig. 3). Elevation, with reference to the contact between the Contrin Formation and the Lower Edifice at the white diamond in figure 3, was computed along each traverse by projecting locations parallel to a representative strike and dip of bedding $\left(330^{\circ}, 10^{\circ} \mathrm{E}\right)$ to a position directly above or below the white diamond. Curves in panel (A) document the decrease in the amount of dolomite relative to limestone with increasing elevation within the Latemar buildup as a whole. Curves in panel (B) document that vertical limestone-dolomite contacts occur almost exclusively below the contact between the Lower Edifice and the Latemar Limestone while both horizontal and vertical limestone-dolomite contacts occur above that contact. 


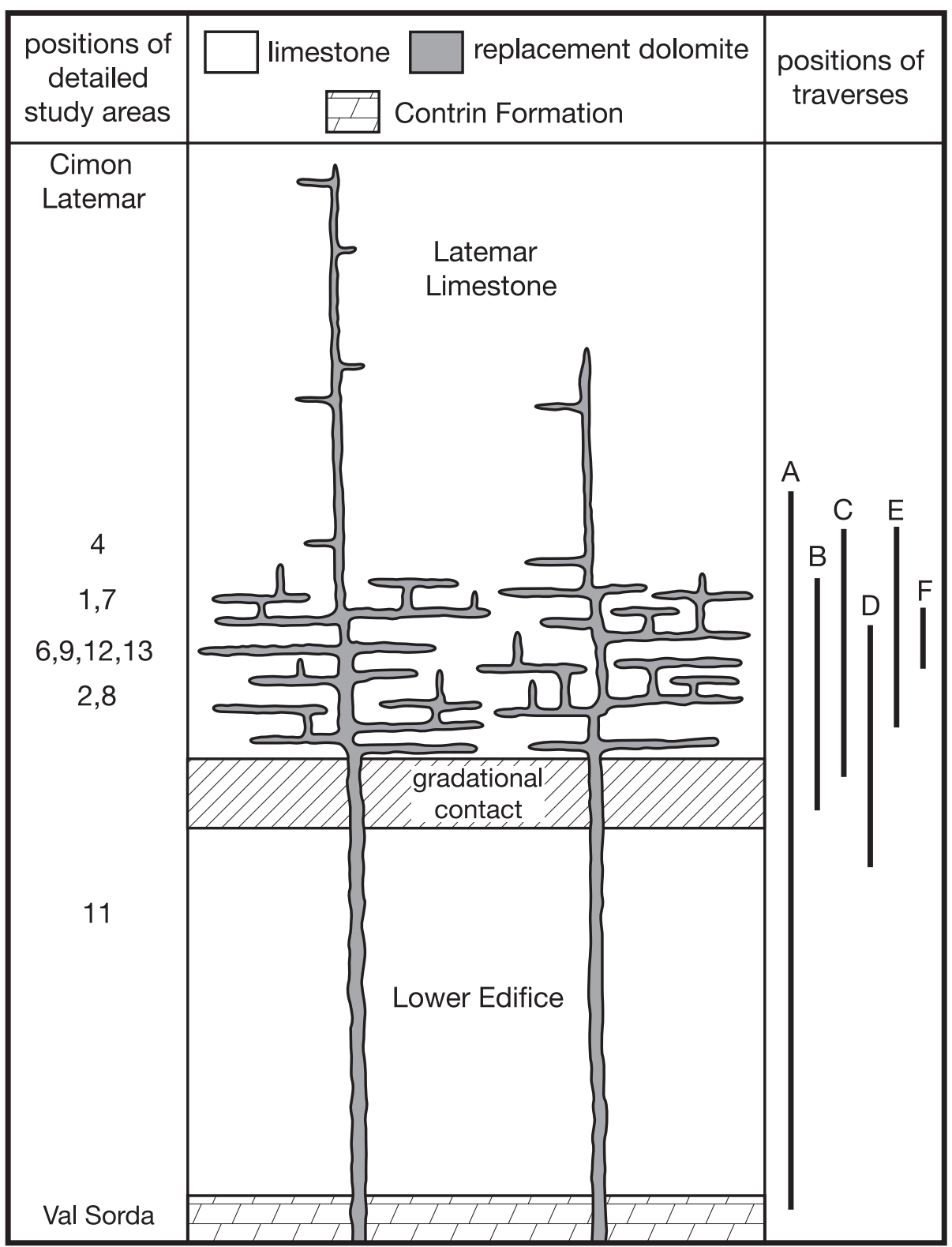

Fig. 13. Synoptic interpretation of the large-scale distribution of replacement dolomite in the Latemar buildup, illustrated in cross section, inferred from maps and photographs in figures 7-11 and data in figure 12. The vertical dimension of the diagram corresponds to $\sim 800 \mathrm{~m}$ of elevation; the horizontal dimension is schematic. The shapes of dolomite bodies are qualitatively correct, but their dimensions are exaggerated for the purposes of illustration. Stratigraphic contacts, locations of sample locations 1-13, and locations of traverses A-F are shown at approximately correct elevations. Replacement dolomite occurs primarily as vertical columns in the Lower Edifice. Significant numbers of layer-parallel tabular and tubular bodies only occur in the Latemar Limestone within $\sim 100 \mathrm{~m}$ of its contact with the Lower Edifice.

elements in calcite and dolomite display three different types of behavior. One group, including $\mathrm{Zn}$ and especially Fe, display positive correlations with $\mathrm{Mn}$ (figs. 16A and 16B). A second, typified by $\mathrm{Cu}$, shows no clearly defined correlation with Mn (fig. 16C); 

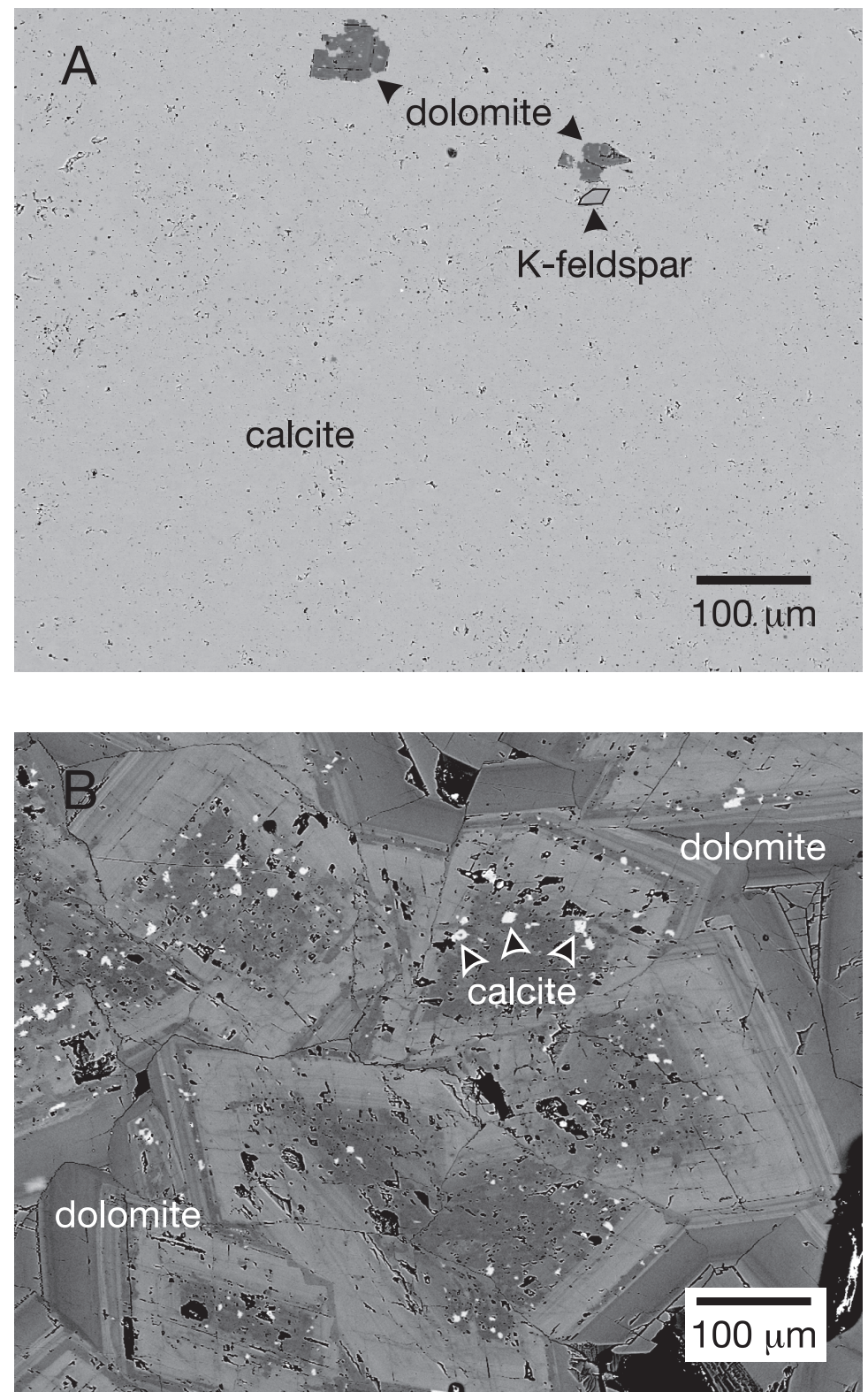

Fig. 14. Backscattered electron (BSE) images of representative samples of limestone (panel A: sample $\mathrm{B}$, location 7) and replacement dolomite (panel B: sample C, location 1) from the Latemar buildup. Black areas are pores and pluck marks. Both rock types are nearly monominerallic. The principal exceptions in limestone are rare isolated grains of dolomite and K-feldspar. The principal exceptions in dolomite are minute calcite inclusions in dolomite.

$\mathrm{Cr}, \mathrm{Co}, \mathrm{Ni}, \mathrm{Ba}$, and $\mathrm{Pb}$ behave similarly (not illustrated). The third type of behavior is that of $\mathrm{Sr}$ whose concentration displays a negative correlation with the concentration of $\mathrm{Mn}$ (also not illustrated). The negative correlation between $\mathrm{Mn}$ and $\mathrm{Sr}$ is not a continuum but results from analyses of calcite with low $\mathrm{Mn}$ and uniformly high $\mathrm{Sr}$ 


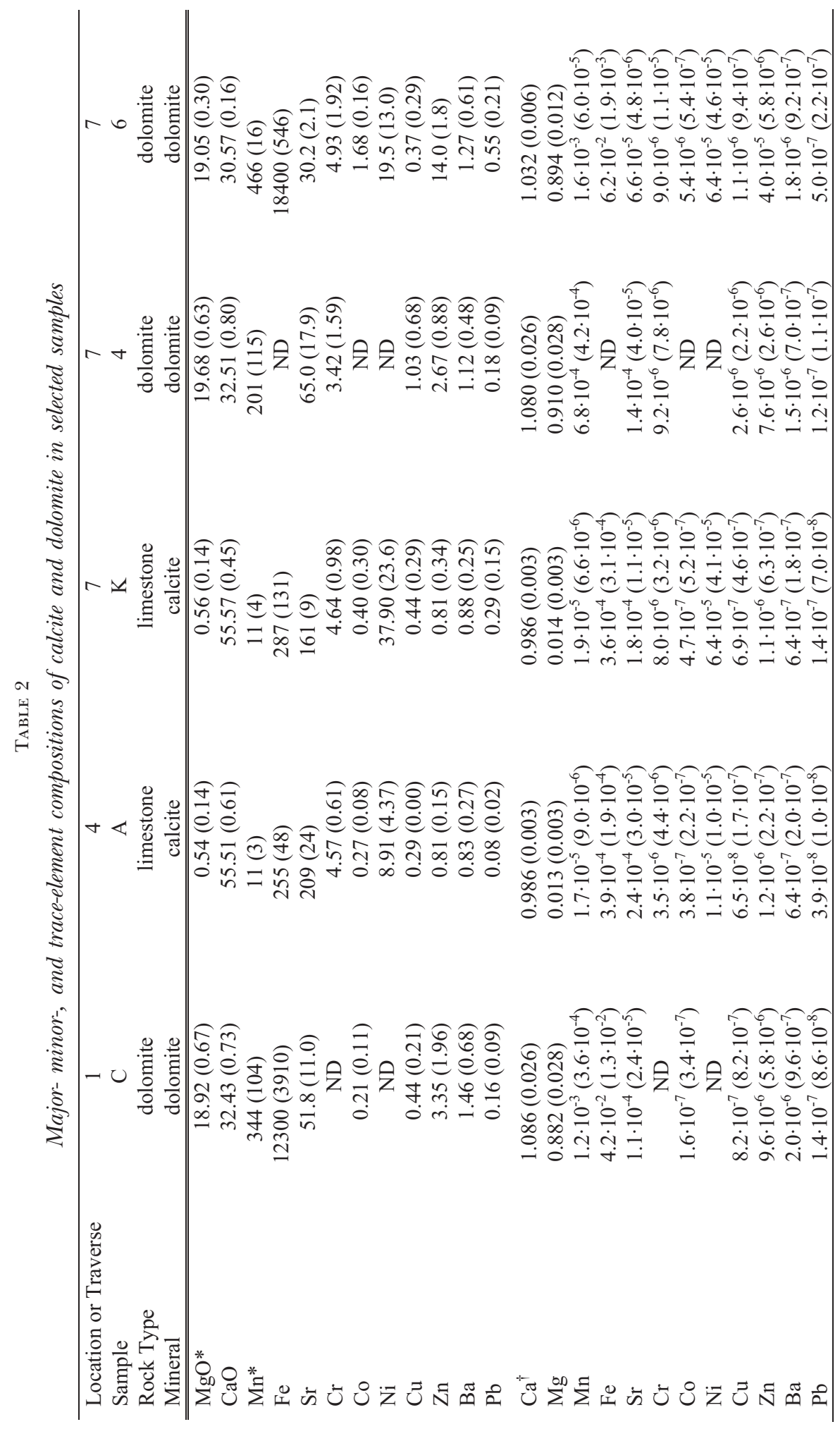




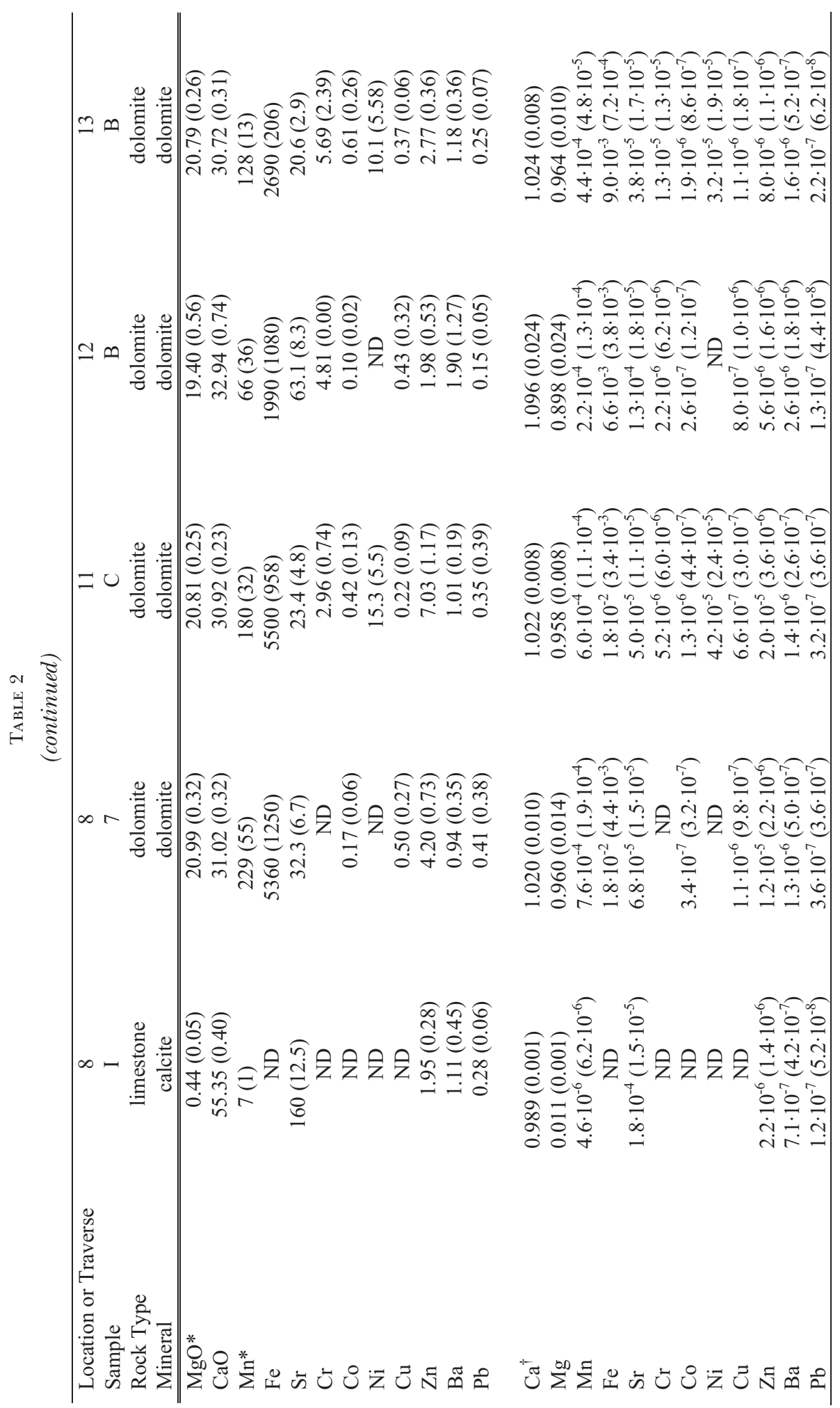




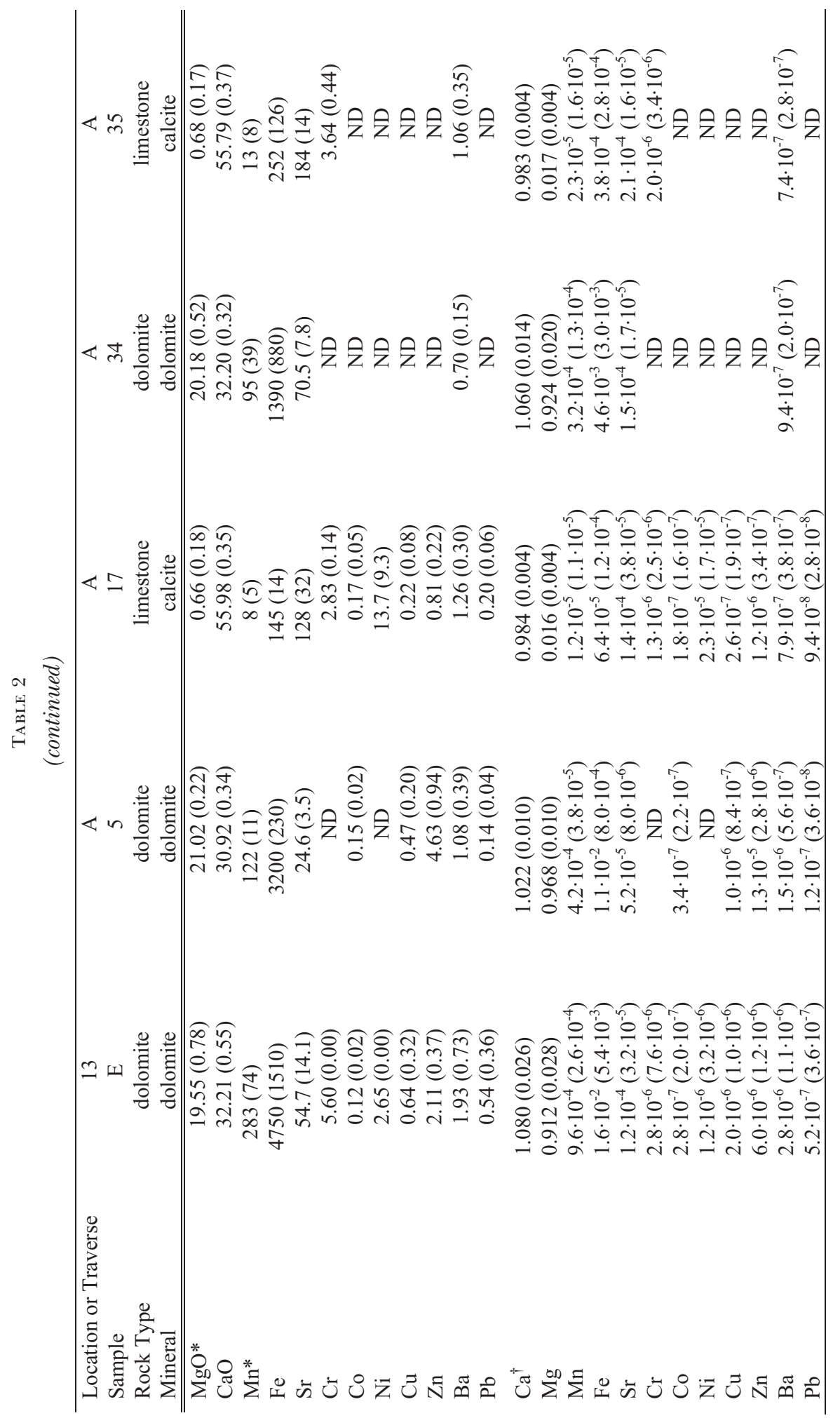




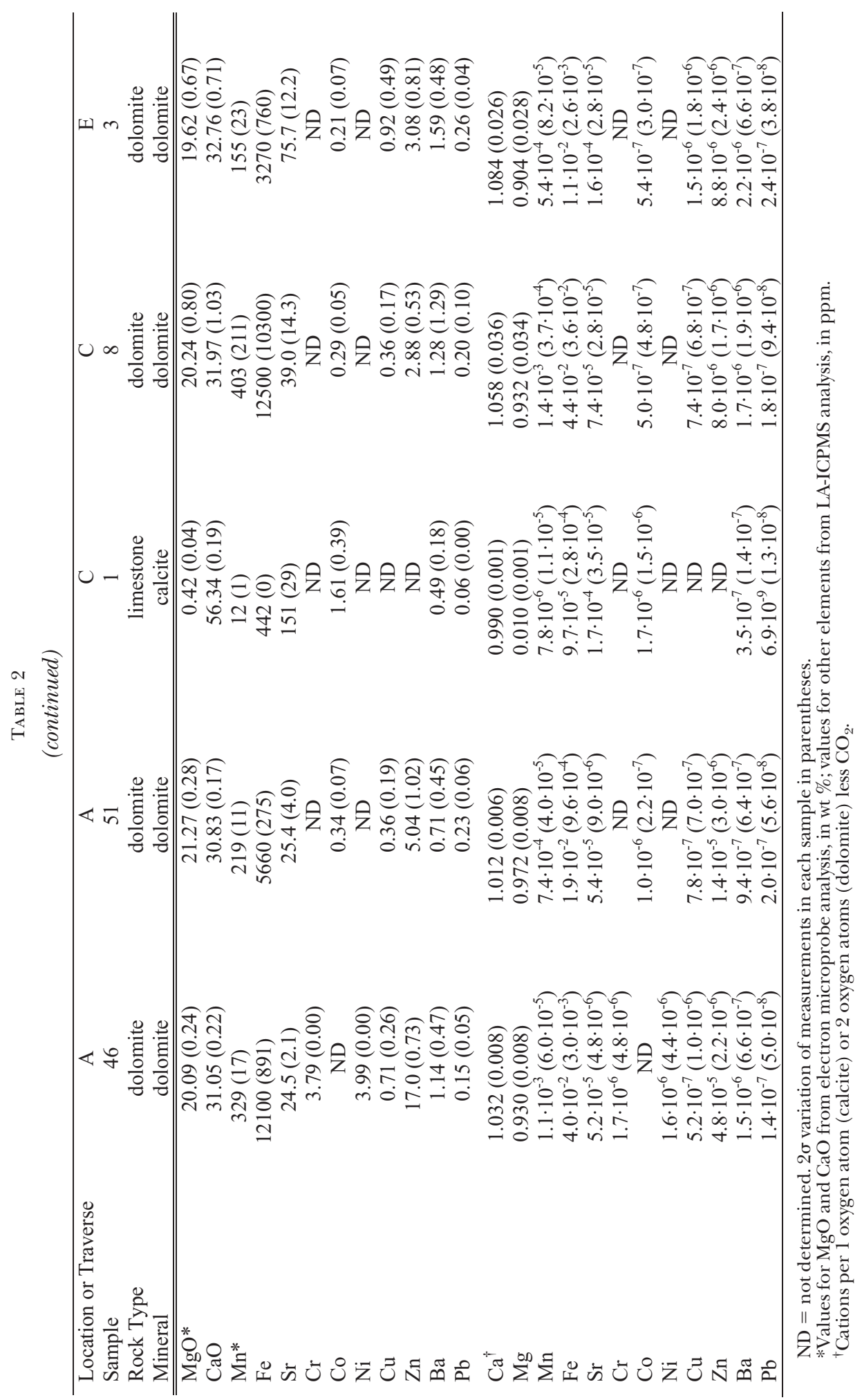



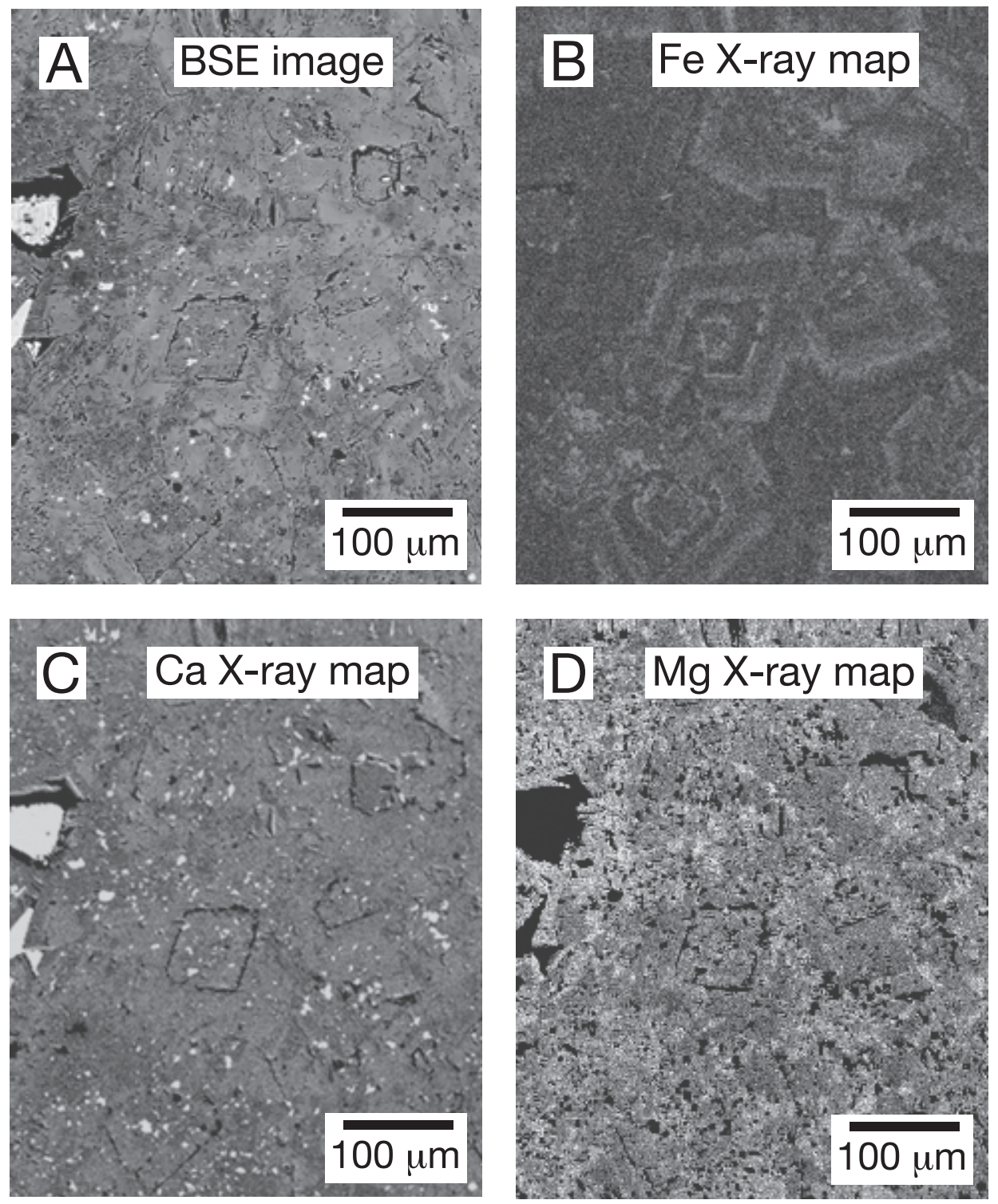

Fig. 15. BSE image and Fe, Ca, and Mg X-ray maps of representative replacement dolomite (sample 3, location 7). Black areas are pores and pluck marks. The X-ray maps demonstrate that the oscillatory zoning observed in BSE images of dolomite (fig. 14B) is caused by variations in the Fe content of dolomite. The oscillatory zoning therefore records temporal variability in the Fe content of the dolomitizing fluid at a single position in the flow system during growth of individual dolomite crystals.

contents and of dolomites with higher Mn and uniformly lower Sr contents. Figure 16 additionally documents that, compared to tan dolomite, orange dolomite tends to be enriched in $\mathrm{Mn}$ and $\mathrm{Zn}$, as well as in $\mathrm{Fe}$, but not in $\mathrm{Cu}$ or any of the other analyzed trace elements (not illustrated).

Comparison of the compositions of calcite and dolomite.-Table 3 compares the composition of calcite in limestone with that of replacement dolomite on the basis of three 

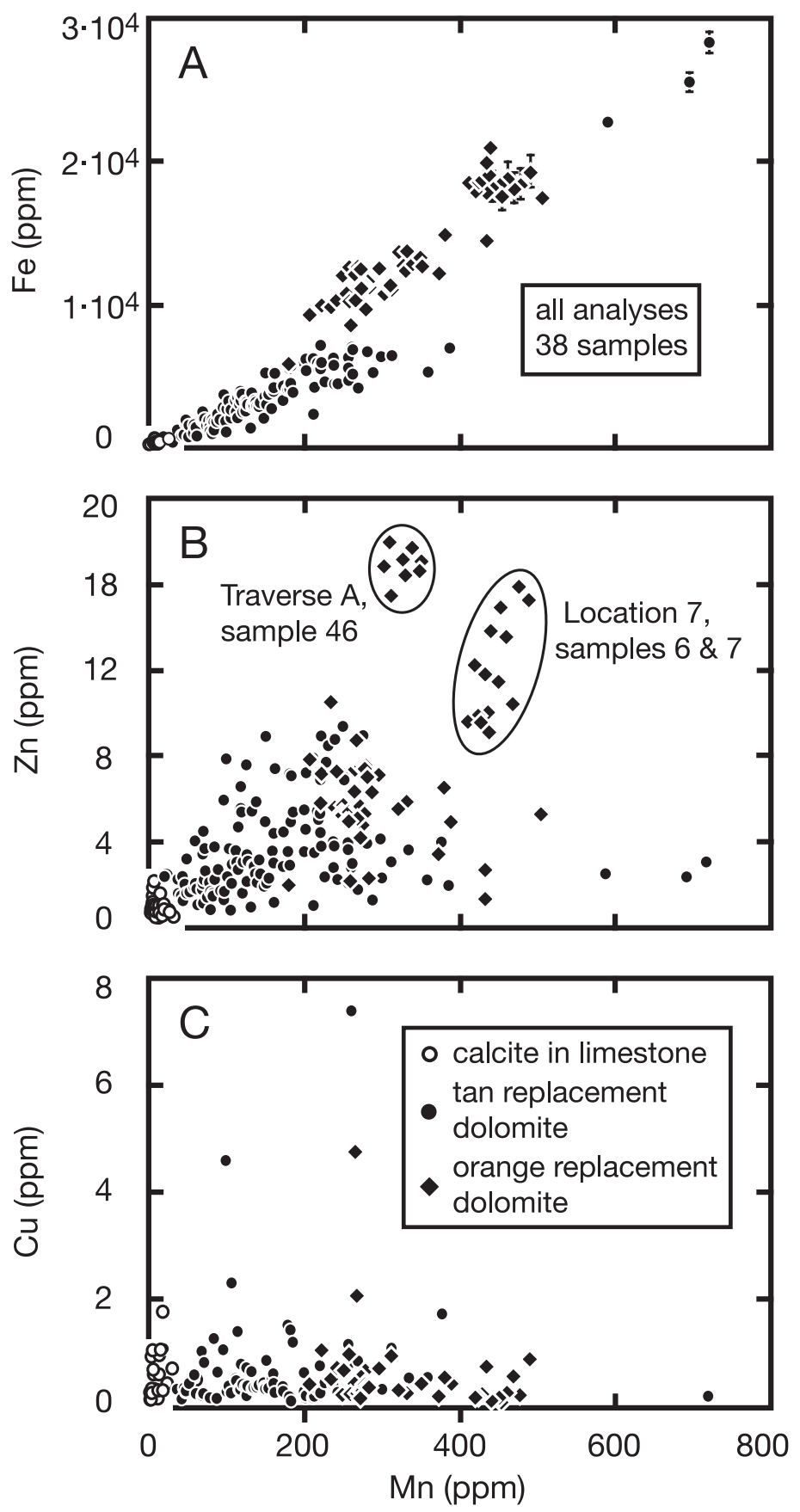

Fig. 16. Concentration of $\mathrm{Fe}(\mathrm{A}), \mathrm{Zn}(\mathrm{B})$, and $\mathrm{Cu}(\mathrm{C})$ plotted against the concentration of $\mathrm{Mn}$ in all LA-ICPMS analyses of calcite and replacement dolomite. Error bars are shown only when they are larger than the size of the symbol. The diagrams illustrate (a) the enrichment of $\mathrm{Mn}, \mathrm{Fe}$, and $\mathrm{Zn}$ but not $\mathrm{Cu}$ in replacement dolomite over calcite; (b) positive correlations among concentrations of $\mathrm{Mn}, \mathrm{Fe}$, and $\mathrm{Zn}$ in dolomite; (c) that the difference in color between tan and orange replacement dolomite likely results from higher concentrations of $\mathrm{Fe}$ and $\mathrm{Mn}$ in orange dolomite; and (d) that the highest measured Zn contents are restricted to just three samples. 
TABLE 3

Average and range of major-, minor-, and trace-element compositions of all analyzed calcite and dolomite

\begin{tabular}{|c|c|c|c|c|c|}
\hline $\begin{array}{c}\text { Cations } \\
\text { per } \\
\mathrm{CO}_{3}{ }^{*}\end{array}$ & & $\begin{array}{l}\text { Calcite in } \\
\text { Limestone }\end{array}$ & Tan Dolomite & Orange Dolomite & $\%$ Overlap $^{\dagger}$ \\
\hline $\mathrm{Ca}$ & $\begin{array}{l}\text { average } \\
\text { range }\end{array}$ & $\begin{array}{l}9.86(0.03) \cdot 10^{-1} \\
(9.82-9.90) \cdot 10^{-1}\end{array}$ & $\begin{array}{l}5.26(0.15) \cdot 10^{-1} \\
(5.05-5.49) \cdot 10^{-1}\end{array}$ & $\begin{array}{l}5.19(0.09) \cdot 10^{-1} \\
(5.10-5.46) \cdot 10^{-1}\end{array}$ & 0 \\
\hline $\mathrm{Mg}$ & $\begin{array}{l}\text { average } \\
\text { range }\end{array}$ & $\begin{array}{l}1.33(0.27) \cdot 10^{-2} \\
(0.99-1.67) \cdot 10^{-2}\end{array}$ & $\begin{array}{l}4.68(0.14) \cdot 10^{-1} \\
(4.47-4.87) \cdot 10^{-1}\end{array}$ & $\begin{array}{l}4.60(0.11) \cdot 10^{-1} \\
(4.34-4.75) \cdot 10^{-1}\end{array}$ & 0 \\
\hline $\mathrm{Mn}$ & $\begin{array}{l}\text { average } \\
\text { range }\end{array}$ & $\begin{array}{l}2.80(1.79) \cdot 10^{-5} \\
(0.03-1.13) \cdot 10^{-4}\end{array}$ & $\begin{array}{l}2.76(1.82) \cdot 10^{-4} \\
(0.04-1.17) \cdot 10^{-3}\end{array}$ & $\begin{array}{l}5.57(1.58) \cdot 10^{-4} \\
(0.84-8.53) \cdot 10^{-4}\end{array}$ & 9 \\
\hline $\mathrm{Fe}$ & $\begin{array}{l}\text { average } \\
\text { range }\end{array}$ & $\begin{array}{c}4.67(2.09) \cdot 10^{-4} \\
(1.85-9.8) \cdot 10^{-4}\end{array}$ & $\begin{array}{l}6.43(6.36) \cdot 10^{-3} \\
(0.04-4.50) \cdot 10^{-2}\end{array}$ & $\begin{array}{l}2.29(0.61) \cdot 10^{-2} \\
(0.99-3.55) \cdot 10^{-2}\end{array}$ & 1 \\
\hline $\mathrm{Zn}$ & $\begin{array}{l}\text { average } \\
\text { range }\end{array}$ & $\begin{array}{l}1.50(0.85) \cdot 10^{-6} \\
(0.61-3.59) \cdot 10^{-6}\end{array}$ & $\begin{array}{l}5.05(3.02) \cdot 10^{-6} \\
(0.11-1.35) \cdot 10^{-5}\end{array}$ & $\begin{array}{l}1.22(0.67) \cdot 10^{-5} \\
(0.19-2.57) \cdot 10^{-5}\end{array}$ & 30 \\
\hline $\mathrm{Sr}$ & $\begin{array}{l}\text { average } \\
\text { range }\end{array}$ & $\begin{array}{l}1.76(0.49) \cdot 10^{-4} \\
(0.44-3.17) \cdot 10^{-4}\end{array}$ & $\begin{array}{l}4.72(2.21) \cdot 10^{-5} \\
(1.69-9.92) \cdot 10^{-5}\end{array}$ & $\begin{array}{l}3.30(1.16) \cdot 10^{-5} \\
(1.84-6.82) \cdot 10^{-5}\end{array}$ & 40 \\
\hline $\mathrm{Cr}$ & $\begin{array}{l}\text { average } \\
\text { range }\end{array}$ & $\begin{array}{l}7.91(4.41) \cdot 10^{-6} \\
(0.26-2.43) \cdot 10^{-5}\end{array}$ & $\begin{array}{l}8.68(3.80) \cdot 10^{-6} \\
(0.29-1.81) \cdot 10^{-5}\end{array}$ & $\begin{array}{l}4.80(2.51) \cdot 10^{-6} \\
(0.22-1.38) \cdot 10^{-5}\end{array}$ & 94 \\
\hline Co & $\begin{array}{l}\text { average } \\
\text { range }\end{array}$ & $\begin{array}{l}1.04(1.08) \cdot 10^{-6} \\
(0.11-3.39) \cdot 10^{-6}\end{array}$ & $\begin{array}{l}5.42(4.86) \cdot 10^{-7} \\
(0.13-2.21) \cdot 10^{-6}\end{array}$ & $\begin{array}{l}1.41(1.04) \cdot 10^{-6} \\
(0.16-3.18) \cdot 10^{-6}\end{array}$ & 100 \\
\hline $\mathrm{Ni}$ & $\begin{array}{l}\text { average } \\
\text { range }\end{array}$ & $\begin{array}{l}3.91(3.66) \cdot 10^{-5} \\
(0.67-14.2) \cdot 10^{-5}\end{array}$ & $\begin{array}{l}1.51(0.94) \cdot 10^{-5} \\
(0.42-3.60) \cdot 10^{-5}\end{array}$ & $\begin{array}{l}1.97(1.89) \cdot 10^{-5} \\
(0.49-6.20) \cdot 10^{-5}\end{array}$ & 82 \\
\hline $\mathrm{Cu}$ & $\begin{array}{l}\text { average } \\
\text { range }\end{array}$ & $\begin{array}{l}7.91(6.24) \cdot 10^{-7} \\
(0.19-2.74) \cdot 10^{-6}\end{array}$ & $\begin{array}{c}9.58(13.80) \cdot 10^{-7} \\
(0.01-1.09) \cdot 10^{-5}\end{array}$ & $\begin{array}{c}8.83(11.30) \cdot 10^{-7} \\
(0.15-7.08) \cdot 10^{-6}\end{array}$ & $94 \%$ \\
\hline $\mathrm{Ba}$ & $\begin{array}{l}\text { average } \\
\text { range }\end{array}$ & $\begin{array}{l}6.23(2.80) \cdot 10^{-7} \\
(0.11-1.45) \cdot 10^{-6}\end{array}$ & $\begin{array}{l}8.32(5.72) \cdot 10^{-7} \\
(0.17-3.66) \cdot 10^{-6}\end{array}$ & $\begin{array}{l}7.36(3.36) \cdot 10^{-7} \\
(0.19-1.79) \cdot 10^{-6}\end{array}$ & $91 \%$ \\
\hline $\mathrm{Pb}$ & $\begin{array}{l}\text { average } \\
\text { range }\end{array}$ & $\begin{array}{l}1.18(0.62) \cdot 10^{-7} \\
(0.28-2.85) \cdot 10^{-7}\end{array}$ & $\begin{array}{l}1.06(0.98) \cdot 10^{-7} \\
(0.22-6.11) \cdot 10^{-7}\end{array}$ & $\begin{array}{l}1.03(0.69) \cdot 10^{-7} \\
(0.28-4.56) \cdot 10^{-7}\end{array}$ & $95 \%$ \\
\hline
\end{tabular}

$2 \sigma$ variation in average follows average value in parentheses.

*Cations per oxygen atom, less $\mathrm{CO}_{2}$.

${ }^{\dagger}$ Percent analyzed dolomite samples with concentration of an element that is within the range of measured values for limestone. 
oxygen atoms and one carbon atom. On average, both tan and orange replacement dolomite are enriched in $\mathrm{Fe}, \mathrm{Mn}$, and $\mathrm{Zn}$ relative to calcite and there is almost no overlap in the concentrations of these elements in calcite and dolomite on a $\mathrm{CO}_{3}$ basis (compare to fig. 16). In contrast, Sr behaves like Ca (table 3) and is depleted in dolomite relative to calcite. Similar to the case of $\mathrm{Cu}$ (fig. 16), the concentrations of all other analyzed trace elements $(\mathrm{Cu}, \mathrm{Ni}, \mathrm{Co}, \mathrm{Cr}, \mathrm{Ba}, \mathrm{Pb})$ almost completely overlap in calcite and dolomite. There is no clearly defined enrichment or depletion of these elements in dolomite relative to calcite.

\section{STABLE ISOTOPE GEOCHEMISTRY}

The oxygen and carbon isotope composition of calcite and dolomite in representative hand specimens of limestone and replacement dolomite are listed in table 4; stable isotope compositions of all analyzed minerals are compiled in Carmichael (ms, 2006).

\section{Variations in $\delta^{18} \mathrm{O}$ and $\delta^{13} \mathrm{C}$ over the Entire Latemar Buildup}

Measured values of $\delta^{18} \mathrm{O}$ of calcite in limestone $\left(\delta^{18} \mathrm{O}_{\mathrm{Cal}}\right)$ and of replacement dolomite $\left(\delta^{18} \mathrm{O}_{\mathrm{Dol}}\right)$ are in the ranges 23.4 to 28.5 permil and 21.8 to 27.7 permil (VSMOW), respectively (fig. 17). Corresponding ranges in $\delta^{13} \mathrm{C}\left(\delta^{13} \mathrm{C}_{\mathrm{Cal}}\right.$ and $\left.\delta^{13} \mathrm{C}_{\mathrm{Dol}}\right)$ are 1.1 to 4.0 permil and 2.0 to 4.6 permil (VPDB), respectively. The stable isotope compositions of dolomite measured in this study compare well with those reported by Wilson and others (1990) for a smaller set of 27 dolomites $\left(\delta^{18} \mathrm{O}_{\text {Dol }}=21.0-29.0 \%\right.$, VSMOW; $\delta^{13} \mathrm{C}_{\text {Dol }}=1.6-4.2 \%$, VPDB). There is no evidence for a systematic difference in $\delta^{13} \mathrm{C}$ or $\delta^{18} \mathrm{O}$ between calcite in bedded limestone and calcite in limestone blocks in breccia columns, nor is there a clear systematic difference in $\delta^{13} \mathrm{C}$ or $\delta^{18} \mathrm{O}$ among analyzed tan replacement dolomite, orange replacement dolomite, or dolomite from breccia (fig. 17). Measured values of $\delta^{18} \mathrm{O}$ and $\delta^{13} \mathrm{C}$ of calcite in limestone from the Latemar buildup lie within the range of unaltered Triassic marine carbonate rocks, $\delta^{18} \mathrm{O} \approx 22$ to 31 permil (VSMOW) and $\delta^{13} \mathrm{C} \approx-1$ to +4 permil (VPDB) (Veizer and Hoefs, 1976; Veizer and others, 1999; Korte and others, 2005).

\section{Variations in $\delta^{18} \mathrm{O}$ and $\delta^{13} \mathrm{C}$ within Individual Outcrops}

Variability in $\delta^{13} \mathrm{C}$ and $\delta^{18} \mathrm{O}$ of calcite and dolomite within individual outcrops was investigated by analyzing 32 samples from location 8 and 31 samples for location 7 (fig. 3). The range in $\delta^{18} \mathrm{O}_{\mathrm{Cal}}$ and $\delta^{13} \mathrm{C}_{\mathrm{Cal}}$ within the two outcrops is smaller than for the Latemar buildup as a whole. The ranges in $\delta^{18} \mathrm{O}_{\text {Dol }}$ at both locations 7 (22.7-27.3\%o) and $8(23.0-27.3 \% 0)$ and in $\delta^{13} \mathrm{C}_{\mathrm{Cal}}$ at location $7(2.0-4.5 \% 0)$, on the other hand, are almost as large as for the Latemar buildup as a whole (fig. 17). The combined range in $\delta^{13} \mathrm{C}_{\mathrm{Cal}}$ and $\delta^{13} \mathrm{C}_{\mathrm{Dol}}$ at location $8(2.0-2.8 \%$ ), however, is only slightly larger than error of measurement $( \pm 0.2 \%, 2 \sigma)$.

DISCUSSION

\section{Geometry of Flow of Dolomitizing Fluid}

As recognized by Wilson and others (1990), the geometry of replacement dolomite bodies is a direct image of the geometry of fluid flow paths where the amount of fluid was sufficient to cause reaction (1). Dolomitizing fluid therefore flowed through the Latemar buildup in a nearly orthogonal lattice of vertical columnar and tabular channels connected to nearly horizontal bedding-parallel tabular and tubular channels (fig. 13). The decreasing amount of dolomite with increasing elevation (fig. 12A) is evidence that the overall direction of flow in the channel network was upwards at low elevations. Flow passed vertically through the Lower Edifice and then ponded by 
TABLE 4

Oxygen and carbon isotope compositions of calcite and dolomite in selected samples

\begin{tabular}{|c|c|c|c|c|}
\hline $\begin{array}{c}\text { Location or } \\
\text { Traverse } \\
\end{array}$ & Sample & Mineral* & $\begin{array}{c}\delta^{13} \mathrm{C} \\
(\% 0 \text { VPDB })\end{array}$ & $\begin{array}{c}\delta^{18} \mathrm{O} \\
(\% \text { VSMOW) }\end{array}$ \\
\hline 1 & $\mathrm{C}$ & dolomite & 2.4 & 23.7 \\
\hline 4 & A & calcite & 2.0 & 26.1 \\
\hline 7 & A & calcite & 2.1 & 25.5 \\
\hline 7 & B & calcite & 2.1 & 25.9 \\
\hline 7 & $\mathrm{~K}$ & calcite & 2.1 & 25.3 \\
\hline 7 & $\mathrm{~L}$ & dolomite & 2.5 & 27.2 \\
\hline 7 & 1 & dolomite & 2.5 & 26.3 \\
\hline 7 & 4 & dolomite & 2.2 & 26.4 \\
\hline 7 & 6 & dolomite & 4.3 & 23.1 \\
\hline 7 & 10 & dolomite & 2.0 & 26.1 \\
\hline 7 & 13 & dolomite & 3.8 & 23.8 \\
\hline 7 & 16 & dolomite & 2.3 & 26.9 \\
\hline 8 & A & calcite & 2.4 & 25.6 \\
\hline 8 & $\mathrm{C}$ & dolomite & 2.6 & 27.1 \\
\hline 8 & $\mathrm{D}$ & dolomite & 2.4 & 25.9 \\
\hline 8 & $\mathrm{~F}$ & calcite & 2.1 & 25.9 \\
\hline 8 & $\mathrm{G}$ & dolomite & 2.4 & 27.3 \\
\hline 8 & I & calcite & 2.2 & 25.1 \\
\hline 8 & $\mathrm{~J}$ & calcite & 2.2 & 28.0 \\
\hline 8 & $\mathrm{O}$ & dolomite & 2.5 & 23.6 \\
\hline 8 & 6 & dolomite & 2.4 & 26.8 \\
\hline 8 & 7 & dolomite & 2.5 & 23.0 \\
\hline 8 & 9 & dolomite & 2.3 & 23.4 \\
\hline 11 & $\mathrm{C}$ & dolomite & 4.0 & 23.9 \\
\hline 12 & B & dolomite & 2.3 & 26.6 \\
\hline 13 & B & dolomite & 2.9 & 22.2 \\
\hline 13 & E & dolomite & 2.4 & 25.8 \\
\hline A & 5 & dolomite & 2.4 & 21.8 \\
\hline A & 17 & calcite & 2.3 & 26.8 \\
\hline A & 34 & dolomite & 2.2 & 27.3 \\
\hline A & 35 & calcite & 2.0 & 28.5 \\
\hline A & 46 & dolomite & 4.3 & 22.6 \\
\hline A & 51 & dolomite & 2.6 & 23.2 \\
\hline A & 55 & dolomite & 4.2 & 23.6 \\
\hline A & 56 & dolomite & 4.6 & 25.3 \\
\hline A & 57 & dolomite & 4.2 & 25.4 \\
\hline $\mathrm{C}$ & 1 & calcite & 1.8 & 26.5 \\
\hline $\mathrm{C}$ & 8 & dolomite & 2.5 & 26.3 \\
\hline E & 3 & dolomite & 2.5 & 27.2 \\
\hline
\end{tabular}

*Analyses of calcite from limestone; analyses of dolomite from replacement dolomite.

spreading out laterally along more permeable bedding planes within the Latemar Limestone. When fluid moved from vertical to nearly horizontal channels, it always moved preferentially in the up-dip direction (fig. 9A). Outcrop-scale interdigitation of 


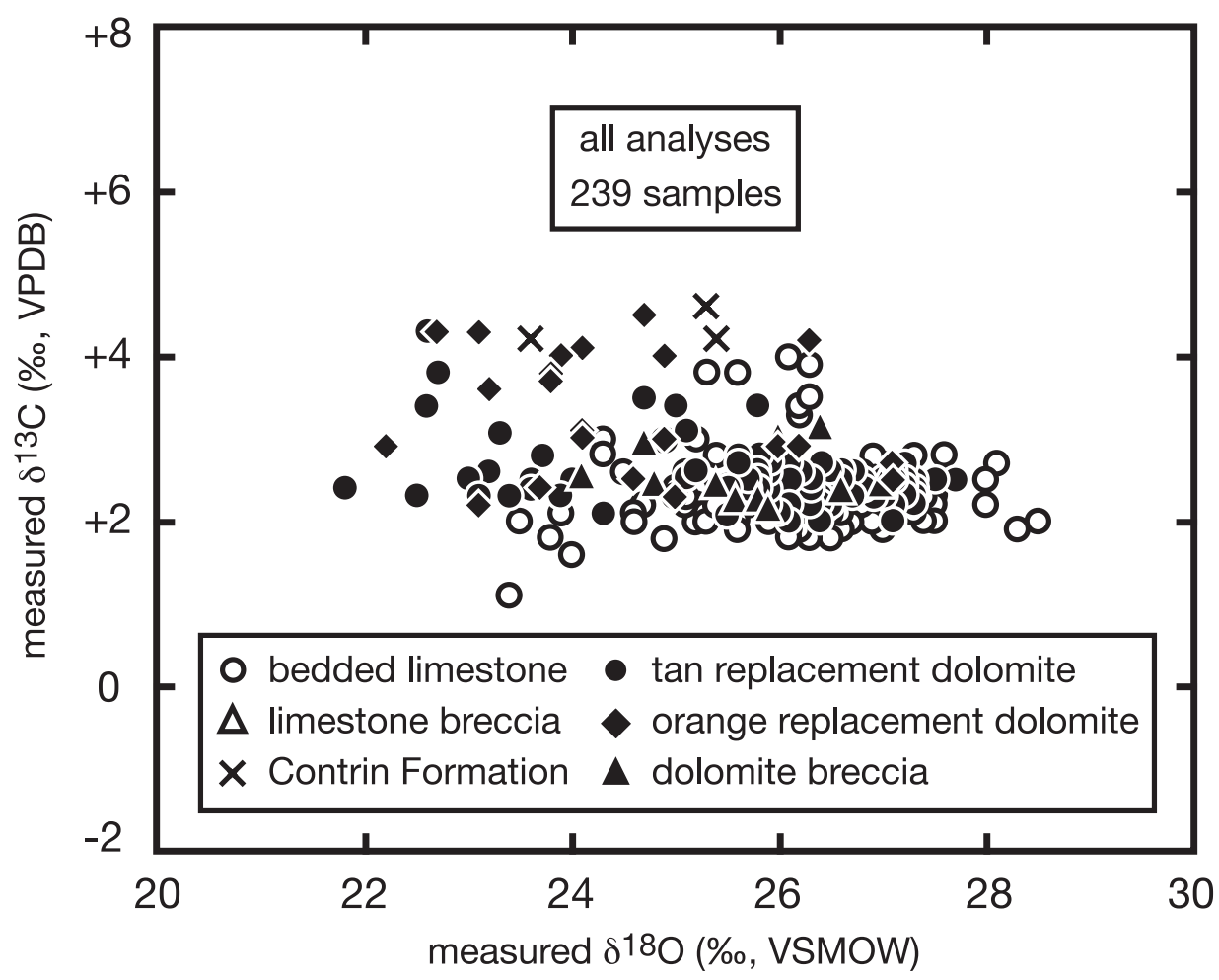

Fig. 17. Measured oxygen and carbon isotope compositions of all 239 analyzed hand specimens of limestone and replacement dolomite from the Latemar buildup. There is no significant difference in carbon or oxygen isotope composition between the different field occurrences of limestone and among the different occurrences of replacement dolomite. The almost complete overlap in $\delta^{13} \mathrm{C}$ of calcite and dolomite indicates that $\delta^{13} \mathrm{C}$ of replacement dolomite in most cases simply was inherited from precursor calcite. The ranges in $\delta^{18} \mathrm{O}_{\mathrm{Cal}}$ and $\delta^{18} \mathrm{O}_{\mathrm{Dol}}$ and values of $\delta^{18} \mathrm{O}_{\mathrm{Dol}}$ less than the lowest value of $\delta^{18} \mathrm{O}_{\mathrm{Cal}}$ reflect oxygen isotope exchange between minerals and fluids either of variable $\delta^{18} \mathrm{O}$, of variable temperature, or both.

limestone and dolomite (figs. 9-11) demonstrates that flow occurred in spatially isolated channels at meter and larger scales. As is observed with chemically reactive fluid flow in contact metamorphic aureoles (reviewed by Ferry and others, 2002), channelization of the flow of dolomitizing fluid in the Latemar buildup was strongly controlled by preexisting structures with elevated permeability such as lithologic contacts, certain bedding planes, and breccia columns.

The geometry of fluid flow represented by figure 13 is not entirely inconsistent with the mushroom-shaped plume of dolomitizing fluid flow proposed by Wilson and others (1990). Our field mapping (figs. 7-12), however, does not support the kind of uniform and pervasive fluid flow implied by figure 11 of Wilson and others (1990). Instead, our data imply that dolomite bodies developed by infiltration of limestone by reactive fluid in spatially restricted channels.

\section{Element Transport and Chemical Constraints on the Origin of Dolomitizing Fluid}

Fluid flow that drove reaction (1) in the Latemar buildup introduced significant amounts of $\mathrm{Fe}, \mathrm{Mn}$, and $\mathrm{Zn}$ as well as $\mathrm{Mg}$ (table 3, fig. 16). Because seawater contains vanishingly small concentrations of $\mathrm{Fe}, \mathrm{Mn}, \mathrm{Zn}$, and other transition metals (Millero and Sohn, 1992), fluid that caused dolomitization could not have simply been 
unmodified seawater as argued by Wilson and others (1990). Furthermore, the dolomitizing fluid must have had $\mathrm{Fe}, \mathrm{Mn}$, and $\mathrm{Zn}$ contents that varied spatially to account for the variations in the $\mathrm{Fe}, \mathrm{Mn}$, and $\mathrm{Zn}$ contents of replacement dolomite at decimeter and larger scales (for example, orange and tan dolomite at location 7 , fig. 9A). Oscillatory zoning of individual dolomite crystals with alternating Fe-rich and Fe-poor growth zones (fig. 14B) is evidence that the Fe, Mn, and $\mathrm{Zn}$ contents of the dolomitizing fluid additionally were variable in time at a given spatial point in the flow system during growth of individual dolomite crystals. Despite variations in the $\mathrm{Fe}, \mathrm{Mn}$, and $\mathrm{Zn}$ contents of the dolomitizing fluid in space and time, relative proportions of $\mathrm{Fe}$, $\mathrm{Mn}$, and $\mathrm{Zn}$ were approximately constant in the fluid (fig. 16).

In contrast, the data in table 3 are consistent with formation of dolomite from calcite at constant $\mathrm{Cu}, \mathrm{Ni}, \mathrm{Co}, \mathrm{Cr}, \mathrm{Ba}$, and $\mathrm{Pb}$. The concentrations of these six elements were sufficiently low in the dolomitizing fluid that dolomite largely or entirely inherited them from reactant calcite as reaction (1) proceeded. The removal of $\mathrm{Sr}$ along with Ca during formation of replacement dolomite (table 3) reflects the incompatibility of $\mathrm{Sr}$ in dolomite compared to calcite, explained by the greater difference between the ionic radius of $\operatorname{Sr}(1.16 \AA)$ and $\mathrm{Mg}(0.72 \AA)$ than between the ionic radius of Sr and Ca (1.00 ̊) (Shannon and Prewitt, 1969).

\section{Controls on the Carbon and Oxygen Isotope Composition of Dolomite}

Most measured values of $\delta^{13} \mathrm{C}_{\mathrm{Cal}}$ and $\delta^{13} \mathrm{C}_{\text {Dol }}$ overlap in the range 2 to 3 permil (fig. 17). The carbon isotope composition of replacement dolomite therefore appears in almost all cases simply to have been inherited from its calcite precursor. Although measured $\delta^{18} \mathrm{O}_{\mathrm{Cal}}$ and $\delta^{18} \mathrm{O}_{\mathrm{Dol}}$ largely overlap (fig. 17), the range for $\delta^{18} \mathrm{O}_{\mathrm{Dol}}$ extends to lower values than the range in $\delta^{18} \mathrm{O}_{\mathrm{Cal}}$ with the lowest measured $\delta^{18} \mathrm{O}_{\text {Dol }}(21.8 \%$ ) 1.6 permil less than the lowest measured $\delta^{18} \mathrm{O}_{\text {Cal }}(23.4 \%$ ). Because dolomite-calcite oxygen isotope fractionation $\left(\delta^{18} \mathrm{O}_{\mathrm{Dol}}-\delta^{18} \mathrm{O}_{\mathrm{Cal}}\right.$ ) is positive (Friedman and O'Neil, 1977; Vasconcelos and others, 2005), replacement dolomite with $\delta^{18} \mathrm{O}_{\text {Dol }}<23.4$ permil could not have been in oxygen isotope exchange equilibrium with any analyzed calcite at any temperature. The ranges in $\delta^{18} \mathrm{O}_{\mathrm{Dol}}$ and $\delta^{18} \mathrm{O}_{\mathrm{Cal}}$ in figure 17 and values of $\delta^{18} \mathrm{O}_{\text {Dol }}<23.4$ permil both indicate that $\delta^{18} \mathrm{O}$ of calcite and dolomite were set by oxygen isotope exchange with the same fluid over a range of temperature, with isotopically different fluids, or both.

Data for samples from location 8 define an almost perfectly horizontal array on a $\delta^{13} \mathrm{C}-\delta^{18} \mathrm{O}$ plot (fig. 18A). Values $\delta^{13} \mathrm{C}$ and $\delta^{18} \mathrm{O}$ for calcite and dolomite from location 8 , where samples of calcite precursor are in close proximity to replacement dolomite, provide a more detailed confirmation of the conclusions drawn from data in figure 17 that $\delta^{13} \mathrm{C}_{\text {Dol }}$ was normally inherited from its precursor calcite and that $\delta^{18} \mathrm{O}_{\text {Dol }}$ was set by oxygen isotope exchange with fluid. Values of $\delta^{18} \mathrm{O}$ for all analyzed samples and values of $\delta^{13} \mathrm{C}$ for limestone and tan replacement dolomite from location 7 (fig. 18B) also conform to the pattern established by samples from location 8 and from the Latemar buildup as a whole. Samples of orange dolomite from location 7 are exceptional for having $\delta^{13} \mathrm{C}$ significantly higher than that of calcite precursors in close proximity. The mismatch in $\delta^{13} \mathrm{C}$ between calcite and orange dolomite at location 7 is a specific example of how a few samples of replacement dolomite in the Latemar buildup had their $\delta^{13} \mathrm{C}$ set by carbon isotope exchange with a fluid rather than by inheritance from a calcite precursor. The range in $\delta^{13} \mathrm{C}_{\text {Dol }}$ of orange dolomite at location 7 is similar to that of dolomite in the underlying Contrin Formation (fig. 18B). Carbon isotopes in the orange dolomite from location 8 could have been derived from the Contrin Formation rather than from local calcite. 

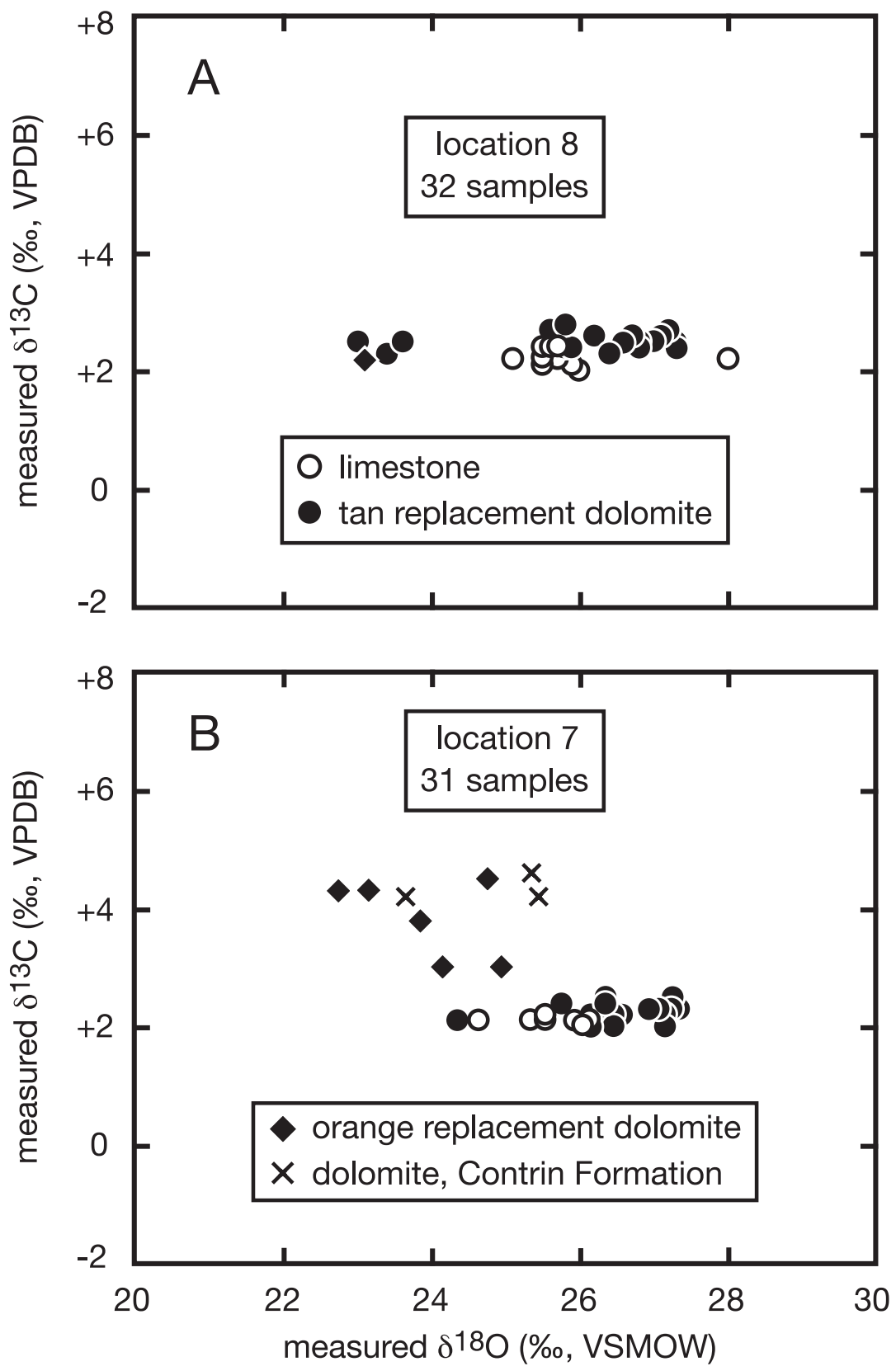

Fig. 18. Measured oxygen and carbon isotope compositions of all analyzed samples of calcite and replacement dolomite from locations 8 (A) and 7 (B). Results for calcite and tan replacement dolomite from locations 7 and 8 demonstrate, in greater detail than data in figure 17 , that $\delta^{13} \mathrm{C}$ of replacement dolomite normally was inherited from precursor calcite and that $\delta^{18} \mathrm{O}_{\mathrm{Cal}}$ and $\delta^{18} \mathrm{O}_{\mathrm{Dol}}$ were set by oxygen isotope exchange of minerals with fluids either of variable $\delta^{18} \mathrm{O}$, of variable temperature, or both. Orange replacement dolomite from location 7 is an example of the rare case of dolomite with $\delta^{13} \mathrm{C}$ significantly different from that of calcite in close proximity. The similarity in $\delta^{13} \mathrm{C}$ between orange dolomite and dolomite from the Contrin Formation indicates that $\delta^{13} \mathrm{C}$ of orange dolomite could have been set by carbon isotopes derived from the underlying Contrin Formation. 


\section{ACKNOWLEDGMENTS}

We thank A. J. Kaufman for providing access to his laboratory at the University of Maryland and Lawrie Hardie, Linda Hinnov, Nereo Preto, and Alberto Riva for advice and education about the Latemar buildup, and the Dolomites in general. Fieldwork was facilitated by logistical support from Nicolas and Antonio Gabrielli and other friends at the Rifugio Torre di Pisa. Laurel Mutti and Sarah Penniston-Dorland assisted with all aspects of mapping and sample collection. Ken Livi and Richard Ash advised on electron microprobe and LA-ICPMS analyses, respectively. We thank John Brady, Peter Nabelek, and an anonymous reviewer for their thoughtful comments. Research supported by grants EAR-0229267 and EAR-0635608, National Science Foundation; by donors of the Petroleum Research Fund, administered by the American Chemical Society; and by endowed funds of the Department of Earth and Planetary Sciences, Johns Hopkins University.

\section{REFERENCES}

Achterbergh, E. V., Ryan, C. G., Jackson, S. E., and Griffin, W. L., 2001, Appendix 3: Data reduction software for LA-ICP-MS, in Sylvester, P., editor, Laser ablation-ICP-MS in the earth sciences: Mineralogical Association of Canada Short Course Series, v. 29, 243 p.

Ague, J. I., 2003, Fluid flow in the deep crust, in Rudnick, R. L., volume editor, The Crust, v. 3, Holland, H. D., and Turekian, K. K., series editors, Treatise on Geochemistry: Amsterdam, Elsevier-Pergamon, p. $195-228$.

Armstrong, J. T., 1988, Quantitative analysis of silicate and oxide minerals: Comparison of Monte Carlo, ZAF, and phi-rho-z procedures, in Newbury, D. E., editor, Microbeam Analysis - 1988: San Francisco, San Francisco Press, p. 239-246.

Baumgartner, L. P., and Valley, J. W., 2001, Stable isotope transport and contact metamorphic fluid flow: Reviews in Mineralogy and Geochemistry, v. 43, p. 415-467, doi:10.2138/gsrmg.43.1.415.

Blendinger, W., 1985, Middle Triassic strike-slip tectonics and igneous activity of the Dolomites (Southern Alps): Tectonophysics, v. 113, p. 105-121, doi:10.1016/0040-1951(85)90112-X.

Brack, P., Mundil, R., Oberli, F., Meier, M., and Rieber, H., 1996, Biostratigraphic and radiometric age data question the Milankovitch characteristics of the Latemar (southern Alps, Italy): Geology, v. 24, p. 371-375, doi:10.1130/0091-7613(1996)024〈0371:BARADQ 2.3.CO;2.

Budd, D. A., 1997, Cenozoic dolomites of carbonate islands: Their attributes and origin: Earth Science Reviews, v. 42, p. 1-47, doi:10.1016/S0012-8252(96)00051-7.

Carmichael, S. K., ms, 2006, Formation of replacement dolomite by infiltration of diffuse effluent: Latemar carbonate buildup, Dolomites, northern Italy: Baltimore, Maryland, The Johns Hopkins University, Ph. D. Thesis, 218 p.

Carraro, A., and Visona, D., 2003, Mantle xenoliths in Triassic camptonite dykes of the Predazzo area (Dolomites, northern Italy): Petrography, mineral chemistry and geothermometry: European Journal of Mineralogy, v. 15, p. 103-115, doi:10.1127/0935-1221/2003/0015-0103.

Cros, P., 1977, Donneé nouvelle sur la dolomitization des carbonates triassiques des Dolomites Italiennes: Sciences de la Terre, v. 21, p. 307-355.

Doglioni, C., 1987, Tectonics of the Dolomites (Southern Alps, northern Italy): Journal of Structural Geology, v. 9, p. 181-193, doi:10.1016/0191-8141(87)90024-1.

Dunn, P. A., ms, 1991, Cyclic stratigraphy and early diagenesis: An example from the Triassic Latemar platform, northern Italy: Baltimore, Maryland, The Johns Hopkins University, Ph. D. Thesis, 836 p.

Egenhoff, S. O., Peterhänsel, A., Bechstädt, T., Zühlke, R., and Grötsch, J., 1999, Facies architecture of an isolated carbonate platform; tracing the cycles of the Latemar (Middle Triassic, northern Italy): Sedimentology, v. 46, p. 893-912, doi:10.1046/j.1365-3091.1999.00258.x.

Ferry, J. M., and Gerdes, M. L., 1998, Chemically reactive fluid flow during metamorphism: Annual Reviews of Earth and Planetary Sciences, v. 26, p. 255-287, doi:10.1146/annurev.earth.26.1.255.

Ferry, J. M., Wing, B. A., Penniston-Dorland, S. C., and Rumble, D., III, 2002, The direction of fluid flow during contact metamorphism of siliceous carbonate rocks: New data for the Monzoni and Predazzo aureoles, northern Italy, and a global review: Contributions to Mineralogy and Petrology, v. 142, p. 679-699. 10.1007/s00410-001-0316-7.

Friedman, I., and O'Neil, J. R., 1977, Compilation of stable isotope fractionation factors of geochemical interest: United States Geological Survey Professional Paper 440-KK, 111 p.

Goldhammer, R. K., ms, 1987, Platform carbonate cycles, Middle Triassic of northern Italy: The interplay of local tectonics and global eustasy: Baltimore, Maryland, The Johns Hopkins University, Ph. D. Thesis, 468 p.

Goldhammer, R. K., Dunn, P. A., and Hardie, L. A., 1987, High frequency glacio-eustatic sealevel oscillations with Milankovitch characteristics recorded in Middle Triassic platform carbonates in northern Italy: American Journal of Science, v. 287, p. 853-892.

1990, Depositional cycles, composite sea-level changes, cycle stacking patterns, and the hierarchy of stratigraphic forcing: Examples from Alpine Triassic platform carbonates: Geological Society of America Bulletin, v. 102, p. 535-562, doi:10.1130/0016-7606(1990) 102〈0535:DCCSLC $\rangle 2.3 . C O ; 2$

Hardie, L. A., 1987, Dolomitization: A critical view of some current views: Journal of Sedimentary Petrology, v. 57 , p. $166-183$. 
Hardie, L. A., Bosellini, A., and Goldhammer, R. K., 1986, Repeated subaerial exposure of subtidal carbonate platforms, Triassic, northern Italy: Evidence for high frequency sea level oscillations on a $10^{4}$ year scale: Paleoceanography, v. 1, p. 447-457, doi:10.1029/PA001i004p00447.

Harris, M., ms, 1988, Margin and foreslope deposits of the Latemar carbonate buildup (Middle Triassic), the Dolomites, northern Italy: Baltimore, Maryland, The Johns Hopkins University, Ph. D. Thesis, 473 p.

Holland, T. J. B., and Powell, R., 1998, An internally consistent thermodynamic data set for phases of petrological interest: Journal of Metamorphic Geology, v. 16, p. 309-343, doi:10.1111/j.15251314.1998.00140.x.

Korte, C., Kozur, H. W., and Veizer, J., 2005, $\delta^{13} \mathrm{C}$ and $\delta^{18} \mathrm{O}$ values of Triassic brachiopods and carbonate rocks as proxies for coeval seawater and paleotemperature: Palaeogeography Palaeoclimatology Palaeoecology, v. 226, p. 287-306, doi:10.1016/j.palaeo.2005.05.018.

Land, L. S., 1985, The origin of massive dolomite: Journal of Geological Education, v. 33, p. 112-125.

Laurenzi, M. A., and Visona, D., 1996, ${ }^{40} \mathrm{Ar} /{ }^{39} \mathrm{Ar}$ chronology of Predazzo magmatic complex (Southern Alps, Italy): Bologna, Italy, Societa Geologica Italiana, Geologia delle Dolomiti, 78a Riunione Estiva.

Leonardi, P., 1955, Breve sintesi geologica delle Dolomiti occidentali: Bollettino della Società Geologica Italiana, v. 74, p. 1-140.

Machel, H. G., and Mountjoy, E. W., 1986, Chemistry and environments of dolomitization-A reappraisal: Earth Science Reviews, v. 23, p. 175-222, doi:10.1016/0012-8252(86)90017-6.

Millero, F. J., and Sohn, M. L., 1992, Chemical oceanography: Boca Raton, Florida, CRC Press, 531 p.

Mundil, R., Brack, P., and Laurenzi, M. A., 1996, High resolution U-Pb single-zircon age determination: New contraints on the timing of Middle Triassic magmatism in the Southern Alps: Bologna, Italy, Societa Geologica Italiana, Geologia delle Dolomiti, 78a Riunione Estiva.

Preto, N., Hinnov, L. A., Hardie, L. A., and De Zanche, V., 2001, Middle Triassic orbital signature recorded in the shallow-marine Latemar carbonate buildup (Dolomites, Italy): Geology, v. 29, p. 1123-1126, doi:10.1130/0091-7613(2001)029〈1123:MTOSRI $>2.0 . C O ; 2$.

Riva, A. M., and Stefani, M. M., 2003, Synvolcanic deformation and intraplatform collapsing: The Latemar case history from the Middle Triassic of the Dolomites: Memorie di Scienze Geologiche, v. 54, p. 139-142.

Rosenbaum, J., and Sheppard, S. M. F., 1986, An isotopic study of siderites, dolomites and ankerites at high temperatures: Geochimica et Cosmochimica Acta, v. 50, p. 1147-1150, doi:10.1016/00167037(86)90396-0.

Rossi, D., 1967, Dolomitizzazione delle formazioni Anisiche e Ladino-Carniche delle Dolomiti: Memorie del Museo Tridentino di Scienze Naturali, Trento, Anno 29-30, v. 16, p. 1-120.

Schubel, K. A., ms, 1997, Reaction mechanisms of dolomitization, an integrated TEM, SEM, geochemical, petrographic and field approach: Baltimore, Maryland, The Johns Hopkins University, Ph. D. Thesis, $352 \mathrm{p}$.

Shannon, R. D., and Prewitt, C. T., 1969, Effective ionic radii in oxides and fluorides: Acta Crystallographica, v. B25, p. 925-946.

Swart, P. K., Burns, S. J., and Leder, J. J., 1991, Fractionation of the stable isotopes of oxygen and carbon in carbon dioxide during the reaction of calcite with phosphoric acid as a function of temperature and technique: Chemical Geology, v. 86, p. 89-96.

Vardebasso, S., 1930, Carta Geologica del Territorio Eruttivo di Predazzo e Monzoni nelle Dolomiti di Fiemme e Fasse, Scale 1:25000, Padova.

Vasconcelos, C., McKenzie, J. A., Warthmann, R., and Bernasconi, S. M., 2005, Calibration of the $\delta^{18} \mathrm{O}$ paleothermometer for dolomite precipitated in microbial cultures and natural environments: Geology, v. 33, p. 317-320, doi:10.1130/G20992.1.

Veizer, J., and Hoefs, J., 1976, The nature of $\mathrm{O}^{18} / \mathrm{O}^{16}$ and $\mathrm{C}^{13} / \mathrm{C}^{12}$ secular trends in sedimentary carbonate rocks: Geochimica et Cosmochimica Acta, v. 40, p. 1387-1395, doi:10.1016/0016-7037(76)90129-0.

Veizer, J., Ala, D., Azmy, K., Bruckschen, P., Buhl, D., Bruhn, F., Carden, G. A. F., Diener, A., Ebneth, S., Godderis, Y., Jasper, T., Korte, C., Pawallek, F., Podlaha, O. G., and Strauss, H., $1999,{ }^{87} \mathrm{Sr} /{ }^{86} \mathrm{Sr}, \delta^{13} \mathrm{C}$ and $\delta^{18} \mathrm{O}$ evolution of Phanerozoic seawater: Chemical Geology, v. 161, p. 59-88, doi:10.1016/S00092541(99)00081-9.

Visona, D., 1997, The Predazzo multipulse intrusive body (Western Dolomites, Italy). Field and mineralogical studies: Memorie di Scienze Geologiche, v. 49, p. 117-125.

Von Damm, K. L., and Lilley, M. D., 2004, Diffuse flow hydrothermal fluids from $9^{\circ} 50$ ’N East Pacific Rise: Origin, evolution and biogeochemical controls, in Wilcock, W. S. D., DeLong, E. F., Kelley, D. S., Baross, J. A., and Cary, S. C., editors, The subsurface biosphere at mid-ocean ridges: American Geophysical Union Geophysical Monograph 144, p. 243-266.

Warren, J., 2000, Dolomite: Occurrence, evolution and economically important associations: Earth Science Reviews, v. 52, p. 1-81, doi:10.1016/S0012-8252(00)00022-2.

Wilson, E. N., Hardie, L. A., and Phillips, O. M., 1990, Dolomitization front geochemistry, fluid flow patterns, and the origin of massive dolomite: The Triassic Latemar buildup, northern Italy: American Journal of Science, v. 290, p. 741-796.

Yose, L., ms, 1993, Stratal patterns and lithofacies in Triassic carbonate slope deposits of the Dolomites, Italy: Implications for sequence stratigraphy and global sea level: Baltimore, Maryland, The Johns Hopkins University, Ph. D. Thesis, 295 p.

Zempolich, W. G., ms, 1995, Deposition, early diagenesis, and late dolomitization of deepwater resedimented oolite: The Middle Jurassic Vajont limestone of the Venetian Alps, Italy: Baltimore, Maryland, The Johns Hopkins University, Ph. D. Thesis, $659 \mathrm{p}$

Zempolich, W. G., and Hardie, L. A., 1997, Geometry of dolomite bodies within deep-water resedimented oolite of the Middle Jurassic Vajont Limestone, Venetian Alps, Italy: Analogs for hydrocarbon reservoirs created through fault-related burial dolomitization, in Kupecz, J. A., Gluyas, J., and Blochs, S., editors, Reservoir Quality Prediction in Sandstones and Carbonates: American Association of Petroleum Geologists Memoir 69, p. 127-162. 